Janusz Józef WĘC

Uniwersytet Jagielloński

janusz.wec@uj.edu.pl

\title{
PROCES IMPLEMENTACJI TRAKTATU LIZBOŃSKIEGO W LATACH 2009-2014
}

ABSTRACT The process of implementing the Lisbon Treaty in the years 2009-2014

The subject of the article is the process of implementing the provisions of the Lisbon Treaty from 13 December 2007 during the first 5 years following its entry into force. The first part of the article introduces implementation actions concerning the EU's institutional system while the second part - works on the implementation of provisions concerning the delegated and implementing acts. The third part has been devoted to the implementation of provisions modifying the principles of democracy and the axiology of the EU, however the fourth part concerns changes in the European Union's common security and defence policy. Finally, the fifth part describes the Irish Protocol containing legal guarantees granted to Ireland by the EU within the domain of the right to life, education and family, tax policy and the security and defence policy.

Key-words: Lisbon Treaty, EU institutions, delegated and implementing acts, axiology of the EU, Irish Protocol, common security and defence policy

Słowa kluczowe: traktat lizboński, instytucje UE, akty delegowane i wykonawcze, aksjologia UE, protokół irlandzki, wspólna polityka bezpieczeństwa i obrony

\section{UWAGI WSTĘPNE}

Przedmiotem artykułu jest proces implementacji przepisów traktatu lizbońskiego z 13 grudnia 2007 r. w okresie pierwszych pięciu lat po jego wejściu w życie. W pierwszej części analizy przedstawione zostały działania implementacyjne dotyczące syste- 
mu instytucjonalnego Unii Europejskiej, zaś w części drugiej prace nad wdrożeniem przepisów odnoszących się do dwóch kategorii aktów nieustawodawczych prawa pochodnego: aktów delegowanych oraz aktów wykonawczych. Część trzecia poświęcona została implementacji postanowień modyfikujących zasady demokratyczne oraz aksjologię Unii Europejskiej, natomiast część czwarta - zmianom we wspólnej polityce bezpieczeństwa i obrony Unii. Wreszcie w części piątej omówione zostały działania mające na celu zastosowanie gwarancji prawnych udzielonych Irlandii przez Unię Europejską w dziedzinie prawa do życia, edukacji i rodziny, polityki podatkowej oraz polityki bezpieczeństwa i obrony.

\section{SYSTEM INSTYTUCJONALNY UNII EUROPEJSKIEJ}

\section{I.1. Parlament Europejski}

Traktat lizboński na mocy art. 14 ust. 2 akapit pierwszy TUE zwiększył całkowitą liczbę deputowanych do Parlamentu Europejskiego z 736 do $751^{1}$. Art. 2 protokołu nr 36 w sprawie postanowień przejściowych, załączonego do TUE, TFUE i TEWEA, stanowil, że $w$ stosownym czasie przed wyborami do Parlamentu Europejskiego w 2009 r., Rada Europejska przyjmie decyzję ustalającą skład Parlamentu zgodnie z art. 14 ust. 2 akapit drugi TUE². Jednocześnie deklaracja nr 5 załączona do Aktu Końcowego konferencji międzyrządowej z 2007 r. przewidywała, że Rada Europejska wyrazi polityczną zgodę na zmieniony projekt decyzji dotyczącej składu Parlamentu Europejskiego w VII kadencji w latach 2009-2014 na podstawie stosownego wniosku Parlamentu ${ }^{3} .14$ grudnia 2007 r., czyli dzień po podpisaniu traktatu lizbońskiego, Rada Europejska podczas posiedzenia w Brukseli wyraziła zgodę na taki nowy projekt decyzji. Sama decyzja Rady Europejskiej w tej sprawie miała być przyjęta jak najszybciej po wejściu w życie traktatu lizbońskiego zgodnie z procedurą ustanowioną w art. 14 ust. 2 akapit drugi TUÉ .

Sprawa nowego projektu decyzji Rady Europejskiej wzięła się stąd, że jeszcze w czasie konferencji międzyrządowej 11 października 2007 r. Parlament Europejski uchwalił rezolucję zawierającą taki projekt. Przewidywał on nowy podział mandatów w Parlamencie Europejskim VII kadencji, uwzględniając przepisy traktatu reformującego, zgodnie z którymi całkowita liczba mandatów nie mogła przekraczać 750, zaś z ini-

Art. 14 ust. 2 ak. 2 TUE.

2 Protokót w sprawie postanowień przejściowych, [w:] Traktat z Lizbony zmieniajacy traktat o Unii Europejskiej i traktat ustanawiający Wspólnotę Europejska, podpisany w Lizbonie 13 grudnia 2007 r. (wersje skonsolidowane) [dalej: Traktat z Lizbony], Dz. U. UE 2008, C 115, s. 322.

3 Szerzej na ten temat por.: J.J. Węc, Traktat Lizboński. Polityczne aspekty reformy ustrojowej Unii Europejskiej w latach 2007-2009, Kraków 2011, s. 102-109, Societas - Ksiegarnia Akademicka, 36; Deklaracja dotycząca politycznej zgody Rady Europejskiej w sprawie projektu decyzji dotyczacej sktadu Parlamentu Europejskiego, [w:] Traktat z Lizbony, s. 337.

4 Posiedzenie Rady Europejskiej w Brukseli, 14 grudnia 2007 r. Konkluzje prezydencji, 16616/1/07, REV 1, Bruksela, 14 II 2008, s. 1. 
cjatywą w tej sprawie występował po raz pierwszy sam Parlament. Projekt został jednak ostro skrytykowany przez delegację włoską podczas posiedzenia Rady Europejskiej w dniach 18-19 października 2007 r., ponieważ przyznawał on Włochom, Wielkiej Brytanii i Francji po raz pierwszy różną liczbę mandatów: i tak Włochy otrzymały 72 mandaty, Wielka Brytania - 73, zaś Francja - 745. Rząd włoski argumentował, że Włochy nie tylko utraciły 6 mandatów w VII kadencji z powodu rozszerzenia Unii Europejskiej, ale przede wszystkim otrzymały we wspomnianym projekcie Parlamentu Europejskiego mniej miejsc aniżeli Francja i Wielka Brytania, mimo iż wcześniej zawsze posiadały taką samą liczbę posłów, jak te dwa państwa. Sprzeciw Włoch spowodował, że Rada Europejska jeszcze podczas tego samego posiedzenia przyjęła wymienioną wyżej deklarację nr 5 .

Gdy przebieg procesu ratyfikacyjnego uzmysłowił rządom państw członkowskich Unii Europejskiej, że traktat lizboński nie wejdzie w życie w planowanym terminie 1 stycznia 2009 r., ponieważ w czterech państwach (RFN, Irlandii, Polsce i Czechach) ratyfikacja natrafiła na trudności ${ }^{6}, 12$ grudnia 2008 r. Rada Europejska uchwaliła deklarację w sprawie postanowień przejściowych dotyczących składu Parlamentu Europejskiego. Przewidywała ona, że o ile traktat lizboński wejdzie w życie po wyborach do Parlamentu Europejskiego zaplanowanych w dniach 4-7 czerwca 2009 r., jak najszybciej przyjęte zostaną środki przejściowe, aby do końca VII kadencji zwiększyć liczbę posłów do Parlamentu pochodzących z dwunastu państw członkowskich, zgodnie z ustaleniami przedstawionymi podczas konferencji międzyrządowej w 2007 r. Chodziło o to, aby umożliwić tym państwom, których liczba mandatów byłaby wyższa, gdyby traktat lizboński obowiązywał w czasie wspomnianych wyborów do Parlamentu Europejskiego - uzyskanie odpowiedniej liczby dodatkowych miejsc i ich obsadzenie. Oznaczało to jednak, że w okresie przejściowym do końca VII kadencji całkowita liczba posłów miałaby wzrosnąć z 736 do $754^{7}$, ponieważ Niemcy musiałyby zachować 99 deputowanych, którzy zostaliby wybrani w wyborach do Parlamentu w czerwcu 2009 r. Albowiem zgodnie z art. 5 Aktu dotyczącego wyborów deputowanych do Parlamentu Europejskiego w powszechnych wyborach bezpośrednich z 20 września 1976 r. nie wolno przerwać mandatu posła w czasie trwania kadencji ${ }^{8}$.

19 czerwca 2009 r. Rada Europejska podjęła decyzję o uzupełnieniu składu Parlamentu Europejskiego we wspomnianym wyżej okresie przejściowym. Do 736 miejsc zapełnionych w wyniku wyborów z 4-7 czerwca 2009 r. postanowiła dodać osiemnaście mandatów, w tym dla Hiszpanii - cztery; Francji, Austrii i Szwecji - po dwa; zaś dla Wielkiej Brytanii, Polski, Włoch, Holandii, Słowenii, Malty, Łotwy i Bułga-

5 Rezolucja Parlamentu Europejskiego z dnia 11 października 2007 r. w sprawie sktadu Parlamentu Europejskiego (2007/2169(INI)), P6_TA(2007)0429, s. 1-6.

6 J.J. Węc, Traktat Lizboński..., s. 281-298.

7 Posiedzenie Rady Europejskiej w Brukseli, $11-12$ grudnia 2008 r. Konkluzje prezydencji, 17271/1/08, REV 1, Bruksela, 13 II 2009, s. 14.

8 Akt dotyczacy wyborów cztonków Parlamentu Europejskiego w powszechnych wyborach bezpośrednich z 20 września 1976 r., s. 1-4, [online] http://oide.sejm.gov.pl/oide/images/files/dokumenty/wybory_pe.pdf, 15 V 2015. 
rii - po jednym mandacie. Państwa te miały wyznaczyć nowych deputowanych zgodnie z obowiązującymi w nich przepisami krajowymi albo spośród osób pochodzących z wyborów uzupełniających do Parlamentu Europejskiego, zorganizowanych specjalnie w tym celu, albo przez odwołanie się do wyborów do Parlamentu Europejskiego z 4-7 czerwca 2009 r., albo spośród posłów bezpośrednio wybranych do danego parlamentu narodowego?.

Postanowienia przejściowe, na jakie się zdecydowano w przypadku składu Parlamentu Europejskiego, wymagały jednak zmiany protokołu nr $36 \mathrm{w}$ sprawie postanowień przejściowych. To z kolei oznaczało konieczność zwołania konferencji międzyrządowej. W ślad za tym zgodnie z art. 48 ust. 2 TUE rząd Hiszpanii, pełniący podówczas funkcję prezydencji w Unii Europejskiej, 4 grudnia 2009 r. przedłożył propozycję zmiany protokołu nr 36. Trzy dni później Rada Unii Europejskiej przedstawiła tę propozycję Radzie Europejskiej, a następnie notyfikowała ją parlamentom narodowym. 11 grudnia 2009 r. Rada Europejska postanowiła skonsultować się z Parlamentem Europejskim i Komisją Europejską w sprawie proponowanych zmian. Podjęła również decyzję o wystosowaniu do Parlamentu prośby o zgodę na niezwoływanie konwentu, albowiem zakres proponowanych zmian nie uzasadniał potrzeby jego zwołania ${ }^{10}$.

28 kwietnia 2010 r. pozytywną opinię na temat konieczności zwołania konferencji międzyrządowej wydała Komisja Europejska. Natomiast 6 maja tegoż roku uczynił to Parlament Europejski, który w uchwalonej wówczas rezolucji wyraził ubolewanie, że Rada Europejska nie przyjęta w stosownym czasie środków umożliwiajacych dodatkowym postom objęcie mandatu już $w$ chwili wejścia $w$ życie traktatu lizbońskiego i $\dot{z} e$ jedno z rozwiązań rozważanych w zmianie, o która wnosi, nie jest zgodne $z$ duchem Aktu z 1976 r., na podstawie którego postowie do Parlamentu Europejskiego powinni być wybierani w wyborach bezpośrednich, a nie pośrednio $w$ drodze wyboru w parlamencie danego państwa cztonkowskiego. Mimo to Parlament Europejski wyraził zgodę na zwołanie konferencji międzyrządowej, zastrzegając, że wspomniane zmiany winny mieć „charakter wyjątkowy”, wynikający ze szczególnych okoliczności ratyfikacji traktatu lizbońskiego, i $w$ żadnym przypadku nie moga być wykorzystywane w przysztości jako precedens. Przypomniał również Radzie Europejskiej, że powinna ona „w stosownym czasie” przed upływem VII kadencji Parlamentu Europejskiego przyjąć decyzję ustalającą jego skład zgodnie z art. 14 ust. 2 TUE oraz że Parlament na mocy tych samych przepisów sam wystąpi z inicjatywą w tej sprawie. Jednocześnie Parlament Europejski poinformował Radę Europejską, że na mocy art. 48 ust. 2 TUE i art. 223 TFUE zamierza on jak najszybciej przedstawić projekt ustanowienia jednakowej dla wszystkich państw członkowskich ordynacji wyborczej. Wezwał on również Radę Europejską do zwołania konwentu w sprawie reformy Parlamentu Europejskiego ${ }^{11}$. W odrębnym do-

9 Posiedzenie Rady Europejskiej w Brukseli, $18-19$ czerwca 2009 r. Konkluzje prezydencji, 11225/2/09, REV 2, Bruksela, 10 VII 2009, s. 24.

10 Posiedzenie Rady Europejskiej w Brukseli, 10-11 grudnia 2009 r. Konkluzje prezydencji, EUCO 6/09, Bruksela, 11 XII 2009, s. 3.

11 Rezolucja Parlamentu Europejskiego z dnia 6 maja 2010 r. dotyczaca projektu protokotu zmieniajacego protokót nr 36 w sprawie przepisów przejściowych w odniesieniu do sktadu Parlamentu Europej- 
kumencie uchwalonym tego samego dnia Parlament podjął decyzję o wyrażeniu zgody na zmianę protokołu nr $36 \mathrm{w}$ ramach konferencji międzyrządowej bez zwoływania konwentu ${ }^{12}$.

17 czerwca 2010 r. Rada Europejska na mocy art. 48 ust. 3 akapit drugi TUE przyjęła mandat konferencji międzyrządowej, który był tożsamy z projektem protokołu zmieniającego protokół nr $36^{13}$. Konferencja międzyrządowa obradowała tylko jeden dzień, 23 czerwca 2010 r., na szczeblu COREPER II, niejako na marginesie posiedzenia Rady Europejskiej w Brukseli. Dlatego jest ona nazywana małą konferencją międzyrządową. Konferencja przyjęła protokół zmieniający protokół nr $36^{14}$. Protokół rewizyjny wymagał ratyfikacji przez wszystkie państwa członkowskie zgodnie z ich wymogami konstytucyjnymi. Miał on wejść w życie 1 grudnia 2010 r., jeżeli do tego czasu złożone zostałyby wszystkie dokumenty ratyfikacyjne lub pierwszego dnia miesiąca następującego po złożeniu dokumentu ratyfikacyjnego przez państwo członkowskie, które jako ostatnie dopełniłoby tej formalności ${ }^{15}$. Wszelako do końca 2010 r. protokół ratyfikowało jedynie jedenaście państw członkowskich Unii Europejskiej. Dopiero po ratyfikacji przez pozostałe państwa protokół wszedł w życie 1 grudnia $2011 \mathrm{r}^{16}$

Nowy art. 2 ust. 1 protokołu nr 36 stanowił, że w okresie od jego wejścia w życie aż do końca VII kadencji Parlamentu Europejskiego do istniejących 736 mandatów, wybranych w wyborach bezpośrednich w dniach 4-7 czerwca 2009 r., dołączonych zostanie osiemnaście mandatów, co zwiększy tymczasowo całkowitą ich liczbę do 754 . Dodatkowe mandaty zostały rozdzielone pomiędzy dwanaście państw członkowskich zgodnie ze wspomnianą wyżej decyzją Rady Europejskiej z 19 czerwca 2009 r. ${ }^{17}$

W zmienionym art. 2 ust. 3 protokołu nr 36 znalazł się również przepis stanowiący, że w stosownym czasie przed wyborami do Parlamentu Europejskiego w 2014 r., Rada

skiego do końca kadencji 2009-2014: opinia Parlamentu Europejskiego (art. 48 ust. 3 traktatu UE) (17196/2009 - C7-0001/2010 - 2009/0813(NLE)), P7_TA(2010)0148, s. 1-3.

12 Decyzja Parlamentu Europejskiego z dnia 6 maja 2010 r. w sprawie wniosku Rady Europejskiej dotyczacego niezwotywania konwentu $w$ celu zmiany traktatów $w$ zakresie środków przejściowych dotyczących sktadu Parlamentu Europejskiego (17196/2009-C7-0002/2010-2009/0814(NLE)), Dz. U. UE 2010, C 81, s. E 175-176.

13 Posiedzenie Rady Europejskiej w Brukseli, 17 czerwca 2010 r. Konkluzje prezydencji, EUCO 13/10, Bruksela, 17 VI 2010, s. 11.

14 KM 2010, Protokót zmieniajacy Protokót w sprawie postanowień przejściowych, dotaczony do Traktatu o Unii Europejskiej, do Traktatu of funkcjonowaniu Unii Europejskiej i do Traktatu ustanawiajacego Europejska Wspólnotę Energii Atomowej, CIG 1/10, Bruksela, 11 VI 2010, s. 1-8; KM 2010, Wstępny porządek obrad konferencji międzyrządowej $w$ dniu 23 czerwca 2010 r.w Brukseli, CIG 2/10, Bruksela, 22 VI 2010, s. 1. Szerzej na temat konferencji międzyrządowej z 23 czerwca 2010 r. por.: J.J. Węc, Spór o ksztatt ustrojowy Wspólnot Europejskich i Unii Europejskiej w latach 1950-2010. Między idea ponadnarodowości a wspótpraca międzyrządową. Analiza politologiczna, Kraków 2012, s. 542-544, Societas - Ksiegarnia Akademicka, 41.

15 Protokót zmieniający protokót w sprawie postanowień przejściowych, dotączony do traktatu o Unii Europejskiej, do traktatu o funkcjonowaniu Unii Europejskiej i do traktatu ustanawiającego Europejską Wspólnotę Energii Atomowej, Dz. U. UE 2010, C 263, s. 3.

16 Szerzej na ten temat por.: J.J. Węc, Spór o ksztatt ustrojowy..., s. 544.

17 Protokót zmieniajacy protokót w sprawie postanowień przejściowych..., s. 2-3. 
Europejska przyjmie decyzję, ustalającą skład Parlamentu zgodnie z art. 14 ust. 2 akapit drugi TUE ${ }^{18}$, czyli tak, aby całkowita liczba posłów w VIII kadencji nie przekraczała 751 osób wraz z przewodniczącym. W ślad za tym 13 maja 2013 r., zgodnie z nowymi przepisami traktatu lizbońskiego, Parlament Europejski wystąpił z inicjatywą ustawodawczą w tej sprawie. 28 czerwca 2013 r. Rada Europejska, po uzyskaniu jego zgody, przyjęła decyzję ustanawiającą skład Parlamentu Europejskiego na okres VIII kadencji wraz ze szczegółowym podziałem mandatów pomiędzy poszczególne państwa członkowskie. Jednocześnie decyzja zawierała przepis stanowiący, że jeszcze przed upływem tejże kadencji Parlamentu Europejskiego dokonany zostanie jej przegląd, umożliwiający ponowny obiektywny, sprawiedliwy, trwaty i przejrzysty podziat mandatów pomiędzy państwa cztonkowskie, odzwierciedlajacy zasadę degresywnej proporcjonalności $i^{19}$.

\section{I.2. Komisja Europejska}

Traktat lizboński dokonał istotnej zmiany w składzie Komisji Europejskiej. W art. 17 ust. 4 TUE stwierdza on bowiem, że w skład Komisji, mianowanej między datą wejścia w życie traktatu lizbońskiego a dniem 31 października 2014 r., wchodzić będzie po jednym przedstawicielu każdego z państw członkowskich, w tym jej przewodniczący i wysoki przedstawiciel Unii ds. zagranicznych i polityki bezpieczeństwa jako jeden $\mathrm{z}$ wiceprzewodniczących. Natomiast w art. 17 ust. 5 TUE traktat lizboński stanowi, że od 1 listopada 2014 r. Komisja Europejska winna się składać z takiej liczby członków, która odpowiada $2 / 3$ ogólnej liczby państw, łącznie z jej przewodniczącym i wysokim przedstawicielem Unii, chyba że Rada Europejska, stanowiąc jednomyślnie, podejmie decyzję o zmianie tej liczby ${ }^{20}$.

Ostatecznie nie doszło jednak do ograniczenia składu Komisji Europejskiej od 1 listopada 2014 r. z powodu sprzeciwu Irlandii. Uzależniła ona swoją zgodę na powtórzenie referendum w sprawie traktatu lizbońskiego od spełnienia przez Unię Europejską kilku warunków, w tym m.in. utrzymania „zasady jeden kraj - jeden komisarz” w Komisji Europejskiej ${ }^{21}$. Polityczną decyzję w tej sprawie przyjęła w dniach 12-13 grudnia 2008 r. Rada Europejska podczas posiedzenia w Brukseli. Zapowiedziała ona wówczas, że - o ile traktat lizboński wejdzie w życie - Rada Europejska, działając zgodnie z niezbędnymi procedurami prawnymi, podejmie decyzję stanowiącą, że $w$ sktad Komisji nadal będzie wchodzić jeden obywatel z każdego państwa cztonkowskiego ${ }^{22}$. Postanowienia te zostały potwierdzone w konkluzjach Rady Europejskiej obradującej w dniach 18-19

18 Tamże, s. 3.

19 Decyzja Rady Europejskiejz dnia 28 czerwca 2013 r. ustanawiająca sktad Parlamentu Europejskiego, Dz. U. UE 2013, L 181, s. 57-58.

20 Art. 17 ust. 4-5 TUE.

21 W pierwszym referendum przeprowadzonym 12 czerwca 2008 r. społeczeństwo Irlandii odrzuciło traktat lizboński większością 53,4\% głosów, przy frekwencji wynoszącej 53,13\%. Szerzej na temat przyczyn negatywnego wobec traktatu wyniku referendum por.: J.J. Węc, Traktat Lizboński..., s. 286-287 .

22 Posiedzenie Rady Europejskiej w Brukseli, 11-12 grudnia 2008 r...., s. 2. 
czerwca 2009 r. w Brukseli ${ }^{23}$. Tym samym przyjęła ona polityczne zobowiązanie o wykorzystaniu przepisów art. 17 ust. 5 TUE w celu powrotu do „zasady jeden kraj - jeden komisarz" na mocy swojej jednomyślnej decyzji.

Gwarancje polityczne uzyskane przez rząd irlandzki podczas posiedzenia Rady Europejskiej w czerwcu 2009 r. w Brukseli ułatwiły mu w znacznej mierze osiągnięcie sukcesu w drugim referendum nad traktatem lizbońskim, które odbyło się 2 października 2009 r. Za traktatem opowiedziało się wówczas aż 67,1\% głosujących, przy frekwencji wynoszącej $59 \%$. Na ostateczny wynik głosowania istotny wpływ miał również przebieg kryzysu finansowego i gospodarczego w świecie, który wybuchł w drugiej połowie 2007 r., oraz przekonanie większości społeczeństwa irlandzkiego, że o wiele łatwiej będzie Irlandii bronić się przed jego skutkami w ramach Unii Europejskiej, aniżeli poza tą organizacją $a^{24}$.

W ślad za tym 22 maja 2013 r. Rada Europejska na mocy art. 17 ust. 5 TUE podjęła decyzję o utrzymaniu zasady ,jeden kraj - jeden komisarz” w składzie Komisji Europejskiej począwszy od 1 listopada 2014 r. (art. 1 decyzji). Z drugiej strony jednak Rada Europejska zastrzegła sobie konieczność dokonania przeglądu tej decyzji pod kątem jej wpływu na funkcjonowanie Komisji Europejskiej po przystąpieniu do Unii Europejskiej trzydziestego państwa członkowskiego lub też po upływie kadencji Komisji, która przejmie swe obowiązki z dniem 1 listopada $2014 \mathrm{r}$. - w zależności od tego, które z tych dwóch wydarzeń przypadnie wcześniej (art. 2 decyzji) ${ }^{25}$.

\section{I.3. Trybunał Sprawiedliwości Unii Europejskiej}

W ramach procesu implementacji przepisów art. 255 TFUE prezes Trybunału Sprawiedliwości wystąpił 11 stycznia 2010 r. z inicjatywą ustalenia zasad działania Komitetu, mającego opiniować kandydatów do wykonywania funkcji sędziego i rzecznika generalnego w Trybunale Sprawiedliwości oraz sędziego w Sądzie - przed ich mianowaniem za wspólnym porozumieniem przez rządy państw członkowskich zgodnie z art. 253 i 254 TFUE. 25 lutego 2010 r. Rada Unii Europejskiej, stanowiąc większością kwalifikowaną, podjęła decyzję określającą zasady działania Komitetu ${ }^{26}$. Zasady te znalazły się w załączniku do wspomnianej decyzji. Komitet składa się z siedmiu członków będących byłymi sędziami Trybunału Sprawiedliwości i Sądu, sędziami krajowych sądów najwyższych lub prawnikami o uznanej kompetencji. Są oni mianowani na okres czterech lat przez Radę Unii Europejskiej, stanowiącą większością kwalifikowaną, na wniosek prezesa Trybunału Sprawiedliwości, przy czym jedną z kandydatur proponuje Parlament Europejski. Mandat członka Komitetu może być jednokrotnie

\footnotetext{
23 Posiedzenie Rady Europejskiej w Brukseli, 18-19 czerwca 2009 r...., s. 2.

24 Szerzej na ten temat por.: J.J. Węc, Traktat Lizboński..., s. 287-291.

25 Decyzja Rady Europejskiej z dnia 22 maja 2013 r. w sprawie liczby cztonków Komisji Europejskiej, Dz. U. UE 2013, L 165, s. 98.

26 Decyzja Rady z dnia 25 lutego 2010 r. w sprawie zasad dziatania komitetu, o którym mowa wart. 255 Traktatu o funkcjonowaniu Unii Europejskiej, Dz. U. UE 2010, L 50, s. 18.
} 
odnowiony. Komitetowi przewodniczy wybrany w tym celu przez Radę Unii Europejskiej jeden z jego członków. Komitet wydaje opinię na temat kandydatów na sędziów i rzeczników generalnych po przeprowadzeniu przesłuchania w czasie niejawnego posiedzenia, chyba że przedmiotem propozycji danego państwa członkowskiego jest jedynie odnowienie mandatu. Opinia wydana przez Komitet jest opatrzona uzasadnieniem i przekazywana przedstawicielom rządów państw członkowskich. Obsługę administracyjną sekretariatu Komitetu zapewnia Sekretariat Generalny Rady Unii Europejskiej ${ }^{27}$.

Podczas konferencji międzyrządowej w 2007 r. delegacja polska kilkakrotnie zgłaszała postulat zwiększenia liczby rzeczników generalnych w Trybunale Sprawiedliwości zgodnie z art. 222 TWE $^{28}$. Otworzyłoby to Polsce drogę do uzyskania jednego stałego rzecznika generalnego $\mathrm{w}$ tej instytucji. Ostatecznie postulat ten udało się przeforsować w czasie posiedzenia Rady Europejskiej w dniach 18-19 października 2007 r. w Lizbonie. Przyjęła ona wówczas deklarację nr 38 dotyczącą liczby rzeczników generalnych w Trybunale Sprawiedliwości. Deklaracja stanowiła, że jeżeli Trybunał Sprawiedliwości, zgodnie z art. 222 TWE (obecnie - art. 252 TFUE), wystąpi do Rady Unii Europejskiej z postulatem zwiększenia liczby rzeczników generalnych o trzy osoby, to Rada, stanowiąc jednomyślnie, wyrazi na to zgodę ${ }^{29}$. W razie zwiększenia o trzy osoby (z ośmiu do jedenastu) liczby rzeczników generalnych, Polsce miałoby przypaść na stałe jedno stanowisko rzecznika generalnego, podobnie jak ma to miejsce w wypadku Niemiec, Francji, Wielkiej Brytanii, Włoch i Hiszpanii. Dwa pozostałe stanowiska zostałyby natomiast włączone do systemu rotacji pomiędzy pozostałymi państwami członkowskimi.

$\mathrm{Na}$ mocy wspomnianej deklaracji delegacja polska uzyskała wprawdzie gwarancję w sprawie przyznania jej stanowiska stałego rzecznika generalnego w Trybunale Sprawiedliwości, ale na jej realizację przyszło czekać ponad dwa lata od wejścia w życie traktatu lizbońskiego. Dopiero 16 stycznia 2013 r. prezes Trybunału Sprawiedliwości wystąpił z wnioskiem o zwiększenie liczby rzeczników generalnych o trzy osoby, uzasadniając to potrzebą usprawnienia prac Trybunału w związku z przyjęciem do Unii Europejskiej w latach 2004 i 2007 nowych państw członkowskich, jak i przyznaniem Trybunałowi przez traktat lizboński nowych kompetencji. W ślad za tym Rada Unii Europejskiej, stanowiąc jednomyślnie, 25 czerwca 2013 r. uchwaliła decyzję o zwiększeniu liczby rzeczników generalnych o trzy osoby. Postanowiła ona również, że nastąpi to w dwóch turach: od 1 lipca 2013 r. liczba rzeczników generalnych zwiększy się do dziewięciu, zaś od 7 października 2015 r. - do jedenastu. Takie dwufazowe rozwiąza-

\section{Tamże, s. 2.}

28 Miało to miejsce podczas spotkania ministrów spraw zagranicznych w formule Gymnich w dniach 6-7 września 2007 r., posiedzenia ministrów spraw zagranicznych 5 października 2007 r. oraz posiedzenia Rady Europejskiej w dniach 18-19 października 2007 r. Por.: J.J. Węc, Traktat Lizboński..., s. 99-109.

29 KM 2007, Sprostowanie do noty od prezydencji do konferencji międzyrządowej. Projekty deklaracji: Deklaracja nr 39a odnosząca się do artykutu 222 Traktatu o funkcjonowaniu Unii Europejskiej w sprawie liczby rzeczników generalnych w Trybunale Sprawiedliwości Unii Europejskiej, CIG 3/1/07, REV 1, COR 2, Bruksela, 22 X 2007, s. 5. 
nie miało - zdaniem Rady - zapewnić m.in. optymalne zintegrowanie się dodatkowych rzeczników generalnych ${ }^{30}$. Ostatecznie 16 października 2013 r. przedstawiciele rządów państw członkowskich za wspólnym porozumieniem, po uzyskaniu pozytywnej opinii Komitetu, mianowali Macieja Szpunara na stanowisko stałego rzecznika generalnego Trybunału Sprawiedliwości ${ }^{31}$.

\section{I.4. Rada Unii Europejskiej}

1 grudnia 2009 r., w dniu wejścia w życie traktatu lizbońskiego, Rada do Spraw Ogólnych, w ramach działań mających na celu implementację przepisów tegoż traktatu, przyjęła decyzję ustanawiającą wykaz wszystkich formacji Rady Unii Europejskiej wraz z Radą do Spraw Ogólnych i Radą do Spraw Zagranicznych, mających jako jedyne status traktatowy. Odtąd formacjami Rady Unii Europejskiej były: 1. Rada do Spraw Ogólnych; 2. Rada do Spraw Zagranicznych; 3. Rada ds. Gospodarki i Finansów (łącznie z Budżetem); 4. Rada ds. Wymiaru Sprawiedliwości i Spraw Wewnętrznych (łącznie z Ochroną Ludności); 5. Rada ds. Zatrudnienia, Polityki Społecznej, Zdrowia i Ochrony Konsumenta; 6. Rada ds. Konkurencji (Rynku Wewnętrznego, Przemysłu i Badań) (łącznie z Turystyką); 7. Rada ds. Transportu, Telekomunikacji i Energii; 8. Rada ds. Rolnictwa i Rybołówstwa; 9. Rada ds. Ochrony Środowiska; 10. Rada ds. Edukacji, Młodzieży i Kultury (łącznie ze Środkami Audiowizualnymi) ${ }^{32}$.

Warto zauważyć, że dwie pierwsze formacje Rady Unii Europejskiej zostały ustanowione na mocy art. 16 ust. 6 TUE, zaś osiem pozostałych na podstawie wspomnianej wyżej decyzji Rady do Spraw Ogólnych z 1 grudnia 2009 r. Wprawdzie art. 236 TFUE stanowił, że decyzję ustanawiającą wykaz formacji Rady Unii Europejskiej, innych niż Rada do Spraw Ogólnych oraz Rada do Spraw Zagranicznych, podejmuje Rada Europejska, stanowiąc większością kwalifikowaną, jednak art. 4 protokołu nr $36 \mathrm{w}$ sprawie postanowień przejściowych dopuszczał warunkowo możliwość uczynienia tego także przez Radę do Spraw Ogólnych. Przewidywał on bowiem, że do wejścia w życie decyzji Rady Europejskiej, dotyczącej wykazu składów Rady Unii Europejskiej, innych niż Rada do Spraw Ogólnych oraz Rada do Spraw Zagranicznych, decyzję ustanawiającą taki wykaz powinna przyjąć sama Rada do Spraw Ogólnych, stanowiąc zwykłą większością głosów (art. 4 protokołu nr 36$)^{33}$.

30 W pierwszym przypadku datą progową był dzień przystąpienia Chorwacji do Unii Europejskiej (pod warunkiem złożenia przed tą datą wszystkich dokumentów ratyfikacyjnych), zaś w drugim wypadku termin częściowego odnowienia składu Trybunału Sprawiedliwości. Por.: Decyzja Rady z dnia 25 czerwca 2013 r. w sprawie zwiększenia liczby rzeczników generalnych Trybunatu Sprawiedliwości Unii Europejskiej, Dz. U. UE 2013, L 179, s. 92.

31 Trybunał Sprawiedliwości Unii Europejkkiej, Komunikat prasowy nr 139/13, Luksemburg, 23 X 2013, s. 1.

32 Decyzja Rady (do Spraw Ogólnych) z dnia 1 grudnia 2009 r. ustanawiajaca wykaz sktadów Rady uzupetniający sktady, o których mowa w art. 16 ust. 6 akapity drugi i trzeci Traktatu o Unii Europejskiej, Dz. U. UE 2009, L 315, s. 46-47.

33 Art. 16 ust. 6 TUE, art. 236 TFUE; Protokót w sprawie postanowień przejśsiowych, [w:] Traktat z Lizbony, s. 323. 
Niespełna dziesięć miesięcy później, 16 września 2010 r. Rada Europejska, działając zgodnie z art. 16 ust. 6 TUE oraz art. 236 TFUE, zmodyfikowała wspomniany wyżej wykaz formacji Rady Unii Europejskiej w taki sposób, ażeby odzwierciedlał on zmiany odnoszące się do przestrzeni kosmicznej i sportu wprowadzone przez traktat lizboński. I tak, do uprawnień Rady ds. Konkurencji (Rynku Wewnętrznego, Przemysłu i Badań) włączone zostały sprawy przestrzeni kosmicznej, zaś do kompetencji Rady ds. Edukacji, Młodzieży i Kultury zagadnienia sportu. Odtąd formacje te noszą nazwy odpowiednio: Rada ds. Konkurencji (Rynku Wewnętrznego, Przemysłu, Badań i Przestrzeni Kosmicznej) oraz Rada ds. Edukacji, Młodzieży, Kultury i Sportu ${ }^{34}$.

\section{I.5. Europejska Służba Działań Zewnętrznych}

1 grudnia 2009 r., czyli również w dniu wejścia w życie traktatu lizbońskiego, Rada Europejska na mocy art. 15 ust. 5 TUE wybrała Hermana Van Rompuy'a na stanowisko jej przewodniczącego na okres od 1 grudnia 2009 r. do 31 maja 2012 r. ${ }^{35} \mathrm{~W}$ tym samym dniu Rada Europejska na podstawie art. 18 ust. 1 TUE, za zgodą przewodniczącego Komisji Europejskiej, powołała Catherine Ashton na stanowisko wysokiej przedstawiciel Unii ds. zagranicznych i polityki bezpieczeństwa. Zgodnie z art. 5 protokołu w sprawie postanowień przejściowych oraz treścią deklaracji nr 12, załączonej do Aktu Końcowego konferencji międzyrządowej z 2007 r., Ashton została mianowana na okres od 1 grudnia 2009 r. do końca trwającej kadencji Komisji Europejskiej ${ }^{36}$.

Od tego momentu rozpoczął się także proces konstytuowania Europejskiej Służby Działań Zewnętrznych (ESDZ) zgodnie z przepisami art. 27 ust. 3 TUE. 21 czerwca 2010 r., podczas wspólnego posiedzenia wysokiej przedstawiciel Unii, reprezentantów prezydencji, Komisji Europejskiej i Parlamentu Europejskiego, osiągnięto polityczny kompromis dotyczący projektu decyzji określającej organizację i zasady funkcjonowania Europejskiej Służby Działań Zewnętrznych. Przyjęto też dwie deklaracje: o współpracy wysokiej przedstawiciel Unii z Parlamentem Europejskim oraz o schemacie organizacyjnym ESDZ ${ }^{37} .26$ lipca 2010 r. Rada do Spraw Ogólnych, działając na wniosek wysokiej przedstawiciel Unii, po uzyskaniu zgody Komisji Europejskiej oraz opinii Parlamentu Europejskiego, przyjęła decyzję w sprawie organizacji i zasad funkcjonowania ESDZ ${ }^{38}$. 1 grudnia 2010 r. ten nowy organ oficjalnie rozpoczął swoją działalność.

34 Decyzja Rady Europejskiej z dnia 16 września 2010 r. w sprawie zmiany wykazu sktadów Rady, Dz. U. UE 2010, L 263, s. 12.

35 Decyzja Rady Europejskiej z dnia 1 grudnia 2009 r. w sprawie wyboru przewodniczacego Rady Europejskiej, Dz. U. UE 2009, L 315, s. 48.

36 Decyzja Rady Europejskiej podjęta za zgodą przewodniczacego Komisji z dnia 1 grudnia 2009 r. w sprawie mianowania wysokiego przedstawiciela Unii ds. zagranicznych i polityki bezpieczeństwa, Dz. U. UE 2009, L 315, s. 49.

37 Informacja dla Sejmu i Senatu o udziale Rzeczypospolitej Polskiej w pracach Unii Europejskiej w okresie styczeń-czerwiec 2010 roku (podczas prezydencji hiszpańskiej), Warszawa 2010, s. 5.

38 Decyzja Rady z dnia 26 lipca 2010 r. określająca organizację i zasady funkcjonowania Europejskiej Stużby Dziatań Zewnętrznych (2010/427/UE), Dz. U. UE 2010, L 201, s. 30-40. Na temat prac przygo- 
Decyzja Rady do Spraw Ogólnych z 26 lipca 2010 r. określała m.in. status, strukturę organizacyjną, personel oraz zadania ESDZ. Decyzja stanowiła, że ESDZ funkcjonalnie jest autonomicznym organem Unii Europejskiej, odrębnym od Sekretariatu Generalnego Rady i od Komisji, posiadającym zdolność prawna niezbędna do wykonywania przypisanych jej zadań i realizacji wyznaczonych jej celów. Ma ona swoją siedzibę w Brukseli. Podlega bezpośrednio wysokiej przedstawiciel Unii. W skład ESDZ wchodzą administracja centralna zlokalizowana w Brukseli oraz delegatury Unii ustanowione w państwach trzecich i przy organizacjach międzynarodowych (art. 1 decyzji) ${ }^{39}$.

$\mathrm{Na}$ czele administracji centralnej ESDZ stoi wykonawczy sekretarz generalny, podlegający bezpośrednio wysokiej przedstawiciel Unii. Jest on odpowiedzialny za skuteczną koordynację działań pomiędzy wszystkimi działami w administracji centralnej oraz delegaturami Unii. Wspomagają go dwaj zastępcy sekretarza generalnego (ds. politycznych oraz ds. stosunków międzyinstytucjonalnych), a także dyrektor ds. operacyjnych. Razem tworzą oni Radę Zarządzającą ESDZ. Administracja centralna ESDZ została podzielona na dyrekcje generalne, na czele których stoją dyrektorzy zarządzający (art. 4 ust. 3 decyzji $)^{40}$. Ostatecznie ustanowiono osiem dyrekcji generalnych. Są to: Dyrekcja Generalna ds. Azji i Pacyfiku; Dyrekcja Generalna ds. Afryki; Dyrekcja Generalna ds. Europy i Azji Środkowej; Dyrekcja Generalna ds. Afryki Północnej, Bliskiego Wschodu, Półwyspu Arabskiego, Iraku i Iranu; Dyrekcja Generalna ds. Ameryk; Dyrekcja Generalna ds. Multilateralnych i Globalnych; Dyrekcja Generalna ds. Reagowania Kryzysowego i Koordynacji Operacyjnej, a także Dyrekcja Generalna ds. Administracji i Finansów ${ }^{41}$.

Na mocy analizowanej decyzji Rady do Spraw Ogólnych do administracji centralnej ESDZ zostały włączone, podlegające odtąd bezpośrednio wysokiej przedstawiciel Unii, niektóre organy wspólnej polityki bezpieczeństwa i obrony. Są to: Sztab Wojskowy Unii Europejskiej, Dyrekcja ds. Zarządzania i Planowania Kryzysowego, Komórka Planowania i Prowadzenia Operacji Cywilnych, a także Centrum Sytuacyjne ${ }^{42}$. Sztab Wojskowy Unii Europejskiej jest odpowiedzialny m.in. za wczesne ostrzeganie, ocenę sytuacji i planowanie strategiczne w zakresie misji petersberskich oraz implementowanie decyzji Komitetu Wojskowego Unii Europejskiej. Dyrekcja ds. Zarządzania i Planowania Kryzysowego, utworzona na mocy analizowanej decyzji Rady do Spraw Ogólnych, zajmuje się procesem planowania operacji Unii Europejskiej w ich najwcześniejszej fazie. Komórka Planowania i Prowadzenia Operacji Cywilnych ma za zadanie planowanie oraz dowodzenie operacjami cywilnymi Unii pod nadzorem Komitetu Politycznego i Bezpieczeństwa. Natomiast Centrum Sytuacyjne, przekształcone później

towawczych do ustanowienia Europejskiej Służby Działań Zewnętrznych por.: J. Lieb, M. Kremer, Der Aufbau des Europäischen Auswärtigen Dienstes. Stand und Perspektiven, „Integration” 2010, nr 3, s. 195-208.

39 Decyzja Rady zdnia 26 lipca 2010 r...., s. 32.

40 Tamże, s. 33.

41 Europejska Służba Działań Zewnętrznych, s. 1, [online] http://eeas.europa.eu/background/organisation/index_pl.htm, 15 V 2015. 
w Centrum Analiz Wywiadowczych Unii Europejskiej, zajmuje się gromadzeniem informacji wywiadowczych na temat potencjalnych lub istniejących kryzysów i konfliktów międzynarodowych, a także opracowywaniem ekspertyz dla wysokiej przedstawiciel Unii, Komitetu Politycznego i Bezpieczeństwa oraz Komitetu Wojskowego Unii Europejskiej ${ }^{43}$.

Jak wspomniano wyżej, w skład ESDZ wchodzą również delegatury Unii Europejskiej usytuowane w państwach trzecich i przy organizacjach międzynarodowych (art. 5 ust. 1-10 decyzji). Zapewniają one tam reprezentację Unii Europejskiej. Delegatury Unii podlegają wysokiej przedstawiciel Unii. Działają w ścisłej współpracy z misjami dyplomatycznymi i konsularnymi państw członkowskich Unii (art. 221 ust. 1-2 TFUE). Szefowie delegatur otrzymują instrukcje od wysokiej przedstawiciel Unii i ESDZ oraz osobiście odpowiadają za ich wykonanie. Na podstawie art. 221 ust. 2 TFUE instrukcje takie mogą oni otrzymywać również od Komisji Europejskiej (art. 5 ust. 3 decyzji). Delegatury Unii wspierają także inne instytucje unijne, w szczególności Parlament Europejski, w ich kontaktach z państwami trzecimi i organizacjami międzynarodowymi. Ponadto wspomagają one państwa członkowskie Unii w ich stosunkach dyplomatycznych i zapewnianiu obywatelom Unii ochrony konsularnej w państwach trzecich (art. 5 ust. 7, 10 decyzji ${ }^{44}$.

Zgodnie z art. 27 ust. 3 TUE w skład ESDZ wchodzą urzędnicy z Sekretariatu Generalnego Rady Unii Europejskiej, urzędnicy z Komisji Europejskiej oraz personel służb dyplomatycznych państw członkowskich Unii. Analizowana decyzja Rady do Spraw Ogólnych stanowiła, że po 1 lipca 2013 r. wszyscy urzędnicy i pracownicy Unii Europejskiej winni mieć możliwość ubiegania się o wakujące stanowiska w ESDZ. Urzędnicy stanowiący personel ESDZ są funkcjonariuszami europejskimi. Reprezentują oni wyłącznie interes Unii Europejskiej. Z wyjątkiem przypadków wspomnianych wyżej, nie zwracają się o instrukcje do żadnego rządu, instytucji, organizacji czy osoby spoza ESDZ, ani takich instrukcji nie przyjmują (art. 5 ust. 4 decyzji) ${ }^{45}$.

Podstawowym zadaniem ESDZ jest wspieranie wysokiej przedstawiciel Unii w wykonywaniu jej obowiązków określonych w art. 17 i art. 27 TUE takich, jak: prowadzenie wspólnej polityki zagranicznej i bezpieczeństwa, w tym wspólnej polityki bezpieczeństwa i obrony, przyczynianie się do konceptualizacji i realizacji tej polityki, a także czuwanie nad spójnością działań zewnętrznych Unii. ESDZ winna również wspomagać przewodniczącego Rady Europejskiej, przewodniczącego Komisji Europejskiej oraz samą Komisję Europejską w wykonywaniu przez nich swoich funkcji w dziedzinie wszystkich działań zewnętrznych (art. 2 ust. 1-2 decyzji) ${ }^{46}$. Ponadto do obowiązków ESDZ należy programowanie i zarządzanie instrumentami wykorzystywanymi w działaniach zewnętrznych Unii. Winno się to odbywać bez naruszania kompetencji Ko-

43 Por. też: R. Formuszewicz, D. Liszczyk, Personel Europejskiej Stużby Dziatań Zewnętrznych do przegladu? Bilans i wnioski z dotychczasowej polityki kadrowej, Raport PISM, Warszawa 2012, s. 1-44.

Decyzja Rady z dnia 26 lipca 2010 r...., s. 34.

45 Tamże, s. 35.

46 Tami̇e, s. 32. 
misji Europejskiej w zakresie zarządzania unijnymi programami współpracy zewnętrznej. Instrumentami tymi są: Instrument Finansowania Współpracy na Rzecz Rozwoju; Europejski Fundusz Rozwoju; Europejski Instrument na Rzecz Wspierania Demokracji i Praw Człowieka na Świecie; Europejski Instrument Sąsiedztwa i Partnerstwa; Instrument Finansowania Współpracy z Państwami Uprzemysłowionymi; Instrument Współpracy w Dziedzinie Bezpieczeństwa Jądrowego, a także Instrument na Rzecz Stabilności (art. 9 ust. 1-2 decyzji) ${ }^{47}$.

\section{I.6. Europejska Agencja Obrony}

Traktat lizboński nadaje status traktatowy Europejskiej Agencji Obrony. W ramach procesu implementacji przepisów art. 45 ust. 2 TUE Rada Unii Europejskiej, stanowiąc większością kwalifikowaną, podjęła 12 lipca 2011 r. decyzję określającą jej statut, siedzibę i zasady funkcjonowania, uwzględniając poziom faktycznego uczestnictwa poszczególnych państw członkowskich w jej pracach ${ }^{48}$. Na mocy tej decyzji uchylone zostało również wspólne działanie Rady Unii Europejskiej z 12 lipca 2004 r., stanowiące dotąd podstawę prawną jej działalności. Europejska Agencja Obrony ma swoją siedzibę w Brukseli, posiada osobowość prawną, podlega zwierzchnictwu Rady Unii Europejskiej, wspierając wspólną politykę zagraniczną i bezpieczeństwa oraz wspólną politykę bezpieczeństwa i obrony, w ramach jednolitych ram instytucjonalnych Unii Europejskiej (art. 1 ust. 2-5 decyzji) ${ }^{49}$. Na jej czele stoi wysoki przedstawiciel Unii, któremu podlega dyrektor generalny oraz Rada Sterująca. Ta ostatnia jest organem decyzyjnym, złożonym z przedstawicieli państw członkowskich Unii uczestniczących w pracach Agencji oraz reprezentanta Komisji Europejskiej (bez prawa głosu). Rada Sterująca zbiera się co do zasady przynajmniej dwa razy w roku na szczeblu ministrów obrony. Może też obradować w składzie przedstawicieli ministrów obrony. W jej posiedzeniach uczestniczą również dyrektor generalny Agencji, przewodniczący Komitetu Wojskowego Unii Europejskiej oraz przedstawiciel Europejskiej Służby Działań Zewnętrznych (art. 6 , art. 7 ust. $1-4$, art. 8 ust. $1-6$ oraz art. 23 ust. 1 decyzji) $)^{50}$.

\section{I.7. Stały Komitet Współpracy Operacyjnej w Zakresie Bezpieczeństwa Wewnętrznego}

Na podstawie art. 71 TFUE traktat lizboński zapowiadał powołanie do życia Stałego Komitetu Współpracy Operacyjnej w Zakresie Bezpieczeństwa Wewnętrznego ${ }^{51}$. Prace przygotowawcze do implementacji tych przepisów traktatu lizbońskiego rozpoczęły się już w lipcu 2009 r. na szczeblu COREPER z udziałem Komisji Europejskiej

Tami̇e, s. 36.

48 Decyzja Rady z dnia 12 lipca 2011 r. określająca statut, siedzibę i zasady operacyjne Europejskiej Agencji Obrony oraz uchylająa wspólne dziatanie 2004/551/WPZiB, Dz. U. UE 2011, L 183, s. 16-26.

49 Tamże, s. 17.

50 Tamże, s. 19, 24.

51 Art. 71 TFUE. 
i Rady Unii Europejskiej ${ }^{52}$. 25 lutego 2010 r. Rada Unii Europejskiej, stanowiąc zwykłą większością głosów, podjęła decyzję o ustanowieniu i zdefiniowaniu zadań Stałego Komitetu. Uzyskał on status jednego z organów przygotowawczych Rady. Ma międzyrządowy charakter. Zapewnia współpracę operacyjną w zakresie bezpieczeństwa wewnętrznego Unii Europejskiej, w szczególności ułatwia koordynację działań operacyjnych właściwych organów państw członkowskich we współpracy policyjnej i celnej, współpracy w zakresie ochrony granic zewnętrznych, a także współpracy sądowej w sprawach karnych, istotnych z punktu widzenia bezpieczeństwa wewnętrznego Unii (art. 71 TFUE, art. 3 decyzji) $)^{53}$. W jego posiedzeniach biorą udział w charakterze obserwatorów przedstawiciele Eurojustu, Europolu, Frontexu i innych właściwych organów. Stały Komitet pomaga zapewniać spójność działań wymienionych organów $\left(\right.$ art. 5 decyzji) ${ }^{54}$.

Stały Komitet Współpracy Operacyjnej w Zakresie Bezpieczeństwa Wewnętrznego wespół z Komitetem Politycznym i Bezpieczeństwa wspomagają Radę Unii Europejskiej, przygotowując w stosowanych przypadkach wspólne opinie (art. 222 TFUE - klauzula solidarności, art. 3 decyzji $)^{55}$. Stały Komitet nie jest zaangażowany ani w przygotowywanie aktów ustawodawczych, ani w prowadzenie operacji, które wciąż należą do kompetencji państw członkowskich (art. 4 decyzji) ${ }^{56}$. Jedynym organem odpowiadającym za przygotowywanie aktów ustawodawczych, z pomocą różnych grup roboczych Rady Unii Europejskiej, jest w tym przypadku COREPER II ${ }^{57}$. Stały Komitet regularnie składa sprawozdania ze swojej działalności Radzie Unii Europejskiej, a ta z kolei informuje Parlament Europejski i parlamenty narodowe (art. 6 decyzji $)^{58}$.

Z uwagi na operacyjne funkcje Stałego Komitetu jego członkami są przedstawiciele ministerstw krajowych, odpowiedzialnych za wymiar sprawiedliwości i spraw wewnętrznych i przez te ministerstwa delegowani. Delegatów do Komitetu wspierają stałe przedstawicielstwa państw członkowskich przy Unii Europejskiej i Sekretariat Generalny Rady Unii Europejskiej. W razie konieczności między głównymi posiedzeniami

52 Prezydencja do Rady i Rady Europejskiej. Sprawozdanie z postepu prac przygotowawczych. Wprowadzenie w żcie traktatu z Lizbony, 17033/1/09 REV 1, Bruksela, 4 XII 2009, s. 4.

53 Art. 71 TFUE; Decyzja Rady z dnia 25 lutego 2010 r. w sprawie ustanowienia Statego Komitetu Wspótpracy Operacyjnej w Zakresie Bezpieczeństwa Wewnętrznego, Dz. U. UE 2010, L 52, s. 50.

54 Decyzja Rady z dnia 25 lutego 2010 r. w sprawie ustanowienia Statego Komitetu..., s. 50.

55 Klauzula ta stanowi, że Unia Europejska mobilizuje wszystkie będące w jej dyspozycji instrumenty, w tym środki wojskowe udostępnione jej przez Państwa Cztonkowskie, by pomóc państwu członkowskiemu będącemu przedmiotem ataku terrorystycznego lub ofiara klęski żywiotowej lub katastrofy spowodowanej przez cztowieka, por.: art. 222 TFUE; Decyzja Rady z dnia 25 lutego 2010 r. w sprawie ustanowienia Statego Komitetu..., s. 50.

56 Decyzja Rady z dnia 25 lutego 2010 r. w sprawie ustanowienia Statego Komitetu..., s. 50.

57 Sekretariat Generalny Rady Unii Europejskiej, Nota informacyjna. Wptyw traktatu lizbońskiego na Radę ds. Wymiaru Sprawiedliwości i Spraw Wewnętrznych: szersza wspótdecyzja i nowe struktury, Bruksela 2009 , s. 3 .

58 Decyzja Rady z dnia 25 lutego 2010 r. w sprawie ustanowienia Statego Komitetu..., s. 50. 
Stałego Komitetu spotykają się radcy tych przedstawicielstw, odpowiadający za kwestie wymiaru sprawiedliwości i spraw wewnętrznych ${ }^{59}$.

\section{I.8. Prokuratura Europejska}

Art. 86 ust. 1 TFUE przewiduje ustanowienie Prokuratury Europejskiej „w oparciu o Eurojust". Przepis ten stanowi, że rozporządzenie o powołaniu Prokuratury Europejskiej do życia może uchwalić Rada Unii Europejskiej, stanowiąc jednomyślnie i w ramach specjalnej procedury ustawodawczej, po uzyskaniu zgody Parlamentu Europejskiego. Jednak przepis ten przewiduje także tzw. hamulec bezpieczeństwa (zwany również klauzulą bezpieczeństwa lub procedurą odwoławczą) - w przypadku braku jednomyślności na forum Rady Unii Europejskiej. Wtedy grupa co najmniej dziewięciu państw członkowskich Unii Europejskiej może zaproponować przekazanie projektu rozporządzenia Radzie Europejskiej, co skutkuje zawieszeniem specjalnej procedury ustawodawczej. Wówczas w ciągu czterech miesięcy od takiego zawieszenia Rada Europejska, po przeprowadzeniu dyskusji, musi osiągnąć consensus w sprawie projektu i odesłać go ponownie Radzie Unii Europejskiej w celu uchwalenia. Jeżeli jednak i tego nie uda się osiągnąć, wtedy co najmniej dziewięć państw członkowskich może ustanowić na podstawie tego projektu wzmocnioną współpracę (art. 86 ust. 1 TFUE) ${ }^{60}$.

Prokuratura Europejska ma być właściwa do zwalczania przestępstw przeciwko interesom finansowym Unii Europejskiej (art. 86 ust. 1 TFUE), w szczególności winna być odpowiedzialna za dochodzenie, ściganie i stawianie przed sądem - w razie potrzeby w powiązaniu z Europolem - sprawców i współsprawców takich przestępstw (art. 86 ust. 2 TFUE). Prokuratura może także wnosić przed właściwe sądy państw członkowskich publiczne oskarżenie w odniesieniu do tychże przestępstw (art. 86 ust. 2 TFUE). Prokuratura winna mieć wyłączną kompetencję do zajmowania się przestępstwami przeciwko interesom finansowym Unii Europejskiej w przeciwieństwie do władzy administracyjnej Europejskiego Urzędu ds. Zwalczania Nadużyć Finansowych (OLAF). Ponadto jej uprawnienia mogą zostać w istotny sposób rozszerzone albo już w czasie prac legislacyjnych nad rozporządzeniem ustanawiającym Prokuraturę Europejską, albo w późniejszym terminie, przez Radę Europejską. Ta ostatnia może bowiem, stanowiąc jednomyślnie i po uzyskaniu zgody Parlamentu Europejskiego oraz konsultacji z Komisją Europejską, przyjąć decyzję o rozszerzeniu kompetencji Prokuratury Europejskiej na zwalczanie poważnej przestępczości o wymiarze transgranicznym (art. 86 ust. 4 TFUE $)^{61}$.

Jak wspomniano wyżej, art. 86 ust. 1 TFUE zawiera zalecenie dotyczące kształtu instytucjonalnego Prokuratury Europejskiej. Stanowi on, że Prokuratura winna być utworzona „w oparciu o Eurojust”. Przepis ten nie jest jednak jednoznaczny. W doktrynie podnosi się, że można go interpretować w taki sposób, iż Prokuratura Europejska

\footnotetext{
59 Sekretariat Generalny Rady Unii Europejskiej, Nota informacyjna..., s. 4.

60 Art. 86 ust. 1 TFUE.

61 Art. 86 ust. 2, 4 TFUE.
} 
winna powstać niejako na bazie Eurojustu, ale po jego wcześniejszym przekształceniu w organ o kompetencjach operacyjnych. Jednak z drugiej strony zwraca się uwagę na fakt, że art. 85 ust. 1 TFUE przewiduje autonomiczne uprawnienia dla Eurojustu, m.in. właśnie w zakresie zwalczania przestępstw przeciwko interesom finansowym Unii Europejskiej. Interpretacja taka oznaczałaby, że Prokuratura Europejska i Eurojust winny być odrębnymi, ale ściśle ze sobą współpracującymi organami ${ }^{62}$.

Takie stanowisko przyjęła również Komisja Europejska w swoim projekcie rozporządzenia Rady Unii Europejskiej w sprawie ustanowienia Prokuratury Europejskiej, który przedłożyła 17 lipca 2013 r. Projekt stanowił, że Prokuratura Europejska winna współpracować z Eurojustem i korzystać z jego wsparcia administracyjnego (art. 3 ust. 3 projektu). Przewidywał on również, że Prokuratura Europejska powinna ustanowić i utrzymywać szczególne stosunki z Eurojustem oparte na ścistej wspótpracy oraz [...] wzajemnych powiazaniach operacyjnych, administracyjnych $i$ zarzadczych (art. 57 ust. 1 projektu $)^{63}$.

Zgodnie z analizowanym projektem rozporządzenia Prokuratura Europejska ma być organem Unii Europejskiej o zdecentralizowanej strukturze, wyposażonym w osobowość prawną (art. 3 ust. 1-2 projektu). W jej skład winien wchodzić prokurator europejski, czterech zastępców oraz co najmniej po jednym delegowanym prokuratorze europejskim, działającym w danym państwie członkowskim. Prokurator europejski ma kierować działalnością Prokuratury Europejskiej oraz organizować jej pracę. Winni go wspomagać, a także zastępować, gdy jest nieobecny lub nie może wypełniać swoich obowiązków, czterej zastępcy prokuratora europejskiego, przy czym jeden z nich ma być odpowiedzialny za budżet. Delegowani prokuratorzy europejscy, działający pod kierownictwem i nadzorem prokuratora europejskiego, mają prowadzić dochodzenia oraz postępowania karne. Powinny być one przeprowadzane na podstawie prawa krajowego. Delegowani prokuratorzy europejscy mogą pełnić swoją funkcję jako prokuratorzy krajowi. Z drugiej strony jednak przy prowadzeniu przydzielonych im dochodzeń i postępowań karnych winni się oni kierować wyłącznie jego instrukcjami, wytycznymi i decyzjami. Muszą być oni w pełni niezależni od krajowych organów ścigania i nie mogą mieć wobec nich żadnych zobowiązań (art. 6 ust. 1-6 projektu) ${ }^{64}$. Działania delegowanych prokuratorów europejskich, wykonujących swe czynności w państwach, w których pełnią oni funkcję prokuratorów krajowych, mają gwarantować zdecentralizowaną strukturę Prokuratury Europejskiej.

Prokuratora europejskiego ma powoływać Rada Unii Europejskiej spośród osób o niekwestionowanej niezależności, mogących zajmować wysokie stanowiska sądowe

62 C. Nowak, Prokuratura Europejska - idea się urzeczywistnia, „Prokuratura i Prawo” 2013, nr 11, s. 24. Por. też: R. Sicurella, Setting up a European Criminal Policy for the Protection of EU Financial Interests. Guidelines for a Coherent Definition of the Material Scope of the European Public Prosecutor's Office, [w:] Toward a Prosecutor for the European Union, Vol. 1: A Comparative Analysis, red. K. Ligeti, OxfordPortland 2013, s. 872.

63 Komisja Europejska, Wniosek. Rozporządzenie Rady w sprawie ustanowienia Prokuratury Europejskiej, $\operatorname{COM}(2013) 534$ wersja ostateczna, Bruksela, 17 VII 2013, s. 18, 44-45. 
oraz posiadających odpowiednie doświadczenie prokuratorskie. Rada stanowi w tej sprawie zwykłą większością głosów i po uzyskaniu zgody Parlamentu Europejskiego. Prokurator europejski powoływany jest na ośmioletnią, nieodnawialną kadencję (art. 8 ust. 1-2 projektu). Zgodnie z tą samą procedurą wybierani są czterej zastęppy prokuratora europejskiego. Z kolei delegowanych prokuratorów europejskich powołuje prokurator europejski z listy co najmniej trzech kandydatów, przedłożonej przez państwa członkowskie. Ich kadencja trwa pięć lat i jest odnawialna. Państwa mianują delegowanego prokuratora europejskiego prokuratorem krajowym, według prawa krajowego, jeżeli w momencie powołania go na stanowisko delegowanego prokuratora europejskiego nie posiadał on jeszcze tego statusu. Prokurator europejski może odwołać delegowanego europejskiego prokuratora, jeżeli dopuścił się on poważnego uchybienia lub przestał spełniać wymienione wyżej kryteria niezbędne do wykonywania swoich obowiązków. Z drugiej strony bez zgody prokuratora europejskiego właściwy organ krajowy nie może odwołać delegowanego prokuratora europejskiego z funkcji prokuratora krajowego w czasie pełnienia przez niego obowiązków na rzecz Prokuratury Europejskiej (art. 10 ust. 1-3 projektu) ${ }^{65}$.

Prokuratura Europejska winna mieć wyłączne kompetencje do dochodzenia i ścigania przestępstw przeciwko interesom finansowym Unii Europejskiej (art. 11 ust. 4 projektu). Uprawnienia te wykonuje ona, jeżeli takie przestępstwo zostało popełnione w całości lub częściowo na terytorium co najmniej jednego państwa członkowskiego lub przez jednego z obywateli państw członkowskich, lub przez członków personelu Unii, lub członków instytucji (art. 14 projektu). Przepisy analizowanego rozporządzenia mają pierwszeństwo przed prawem krajowym w zakresie czynności procesowych. Prawo krajowe danego państwa członkowskiego, w którym będzie prowadzone postępowanie przygotowawcze, wydawana decyzja o sposobie jego zakończenia lub kierowany akt oskarżenia, ma mieć zastosowanie jedynie w takim zakresie, w jakim dana sprawa nie jest uregulowana rozporządzeniem. W przypadku, gdy dana sprawa jest uregulowana prawem krajowym i rozporządzeniem, pierwszeństwo mają przepisy rozporządzenia (art. 11 ust. 3 projektu) ${ }^{66}$.

Projekt analizowanego rozporządzenia został 18 lipca 2013 r. przekazany przez Komisję Europejską Radzie Unii Europejskiej i Parlamentowi Europejskiemu, ale proces legislacyjny znajduje się dopiero w początkowej fazie. Dotrzymanie pierwotnie planowanego terminu - 1 stycznia 2015 r. jako daty powołania do życia Prokuratury Europejskiej - stało się niemożliwe. Po wydaniu opinii przez Komitet Ekonomiczno-Społeczny (11 grudnia 2013 r.) i Komitet Regionów (30 stycznia 2014 r.) 4 marca 2014 r. rozpoczęła się - trwająca nadal - debata w Radzie Unii Europejskiej i jej organach przygotowawczych ${ }^{67}$.

65 Tamże, s. 20-21.

66 Tamże, s. 21-22. Analizę projektu rozporządzenia por.: G. Stronikowska, Propozycja Komisji Europejskiej dotycząca rozporządzenia Rady w sprawie utworzenia Prokuratury Europejskiej (część 1), „Prokuratura i Prawo" 2014, nr 6, s. 65.

67 Procedura 2013/0255/APP COM (2013) 534: Wniosek rozporzadzenie Rady w sprawie ustanowienia Prokuratury Europejskiej, Eur-Lex. Baza aktów prawnych unii Europejskiej, s. 1, [online] http:// 


\section{AKTY PRAWA POCHODNEGO: DELEGOWANE I WYKONAWCZE}

\section{II.1. Akty delegowane}

Jeszcze przed wejściem w życie traktatu lizbońskiego, w lipcu 2009 r., rozpoczęły się prace przygotowawcze do implementacji jego przepisów dotyczących aktów delegowanych Komisji Europejskiej, czyli aktów o charakterze nieustawodawczym o zasięgu ogólnym, które uzupetniają lub zmieniają niektóre, inne niż istotne, elementy aktu ustawodawczego (art. 290 ust. 1-3 TFUE) ${ }^{6}$. Należy podkreślić, że uprawnienia do uchwalania aktów delegowanych przez Komisję Europejską mogły być jej przekazywane jedynie na podstawie aktów ustawodawczych, czyli aktów prawnych przyjmowanych w ramach zwykłej lub specjalnej procedury ustawodawczej (art. 289 ust. 1-3 TFUE) ${ }^{69}$.

Prace przygotowawcze do implementacji wskazanych przepisów były prowadzone na szczeblu COREPER I z udziałem przedstawicieli Komisji Europejskiej i Rady Unii Europejskiej $^{70} .9$ grudnia 2009 r. Komisja Europejska przesłała do Parlamentu Europejskiego i Rady Unii Europejskiej komunikat określający warunki współpracy podczas wydawania przez nią aktów delegowanych ${ }^{71}$. O ile Rada wyraziła poparcie dla tego dokumentu, o tyle Parlament Europejski sprzeciwił się propozycjom Komisji. Przepisy art. 290 ust. 2 lit a-b TFUE przewidywały kontrolę Parlamentu Europejskiego i Rady Unii Europejskiej nad wykonywaniem przez Komisję Europejską jej uprawnień w dwojaki sposób: po pierwsze, przez wykorzystywanie prawa sprzeciwu wobec konkretnego aktu delegowanego w terminie przewidzianym przez akt ustawodawczy; po drugie, przez odwołanie uprawnień do ich wydawania ${ }^{72}$. Przepisy te obowiązywały bezpośrednio i nie przewidywały przyjęcia dodatkowych regulacji prawnych w celu ich stosowania. Jednak sprzeciw Parlamentu Europejskiego wobec treści komunikatu Komisji spowodowat, że podjęto decyzję o ustanowieniu praktycznych rozwiązań dotyczących procedur przyjmowania aktów delegowanych oraz sprawowania nad nimi kontroli przez Parlament Europejski i Radę Unii Europejskiej. W trakcie negocjacji prowadzonych między Komisją Europejską a Parlamentem Europejskim postanowiono zawrzeć porozumienie międzyinstytucjonalne, regulujące procedurę wydawania aktów delegowanych. Zostało ono przyjęte 8 grudnia 2010 r. na szczeblu COREPER I. W wyniku

eur-lex.europa.eu/legal-content/ PL/HIS/, 15 V 2015. Dnia 12 marca 2014 r. Parlament Europejski uchwalił wstępny raport oraz rezolucję legislacyjną do projektu Komisji Europejskiej, por.: Rezolucja Parlamentu Europejskiego $z$ dnia 12 marca 2014 r. w sprawie wniosku dotyczacego rozporzadzenia Rady w sprawie ustanowienia Prokuratury Europejskiej, P7_TA-PROV(2014)0234, s. 1-11.

Art. 290 ust. 1-3 TFUE.

69 Art. 289 ust. 1-3 TFUE.

70 Prezydencja do Rady i Rady Europejskiej. Sprawozdanie z postępu prac przygotowawczych..., s. 5.

71 Komisja Europejska, Komunikat Komisji do Parlamentu Europejskiego i Rady. Wprowadzenie w życie art. 290 Traktatu ofunkcjonowaniu Unii Europejskiej, COM(2009) 673 wersja ostateczna, Bruksela, 9 XII 2009, s. 1-14.

72 Art. 289 ust. 2 lit. a-b TFUE. 
dalszych negocjacji w marcu 2011 r. zostało ono zatwierdzone przez Parlament Europejski, zaś w kwietniu tegoż roku ostatecznie zaakceptował je COREPER I ${ }^{73}$.

Porozumienie to zawiera szczegółowe postanowienia regulujące m.in. sposób wykonywania przez Komisję Europejską jej uprawnień do wydawania aktów delegowanych oraz kompetencje kontrolne Parlamentu Europejskiego i Rady Unii Europejskiej. W zależności od charakteru aktu podstawowego uprawnienia do przyjmowania aktów delegowanych mają być przekazywane Komisji Europejskiej na czas określony lub nieokreślony. Ostatecznie procedura wykonywania przez Komisję Europejską uprawnień do wydawania aktów delegowanych wygląda następująco: Przed przyjęciem projektu aktu delegowanego Komisja Europejska musi przeprowadzić konsultacje eksperckie, w tym także z państwami członkowskimi. Po wydaniu tegoż projektu Komisja winna niezwłocznie notyfikować go równocześnie Parlamentowi Europejskiemu i Radzie Unii Europejskiej. W uzasadnionych przypadkach obowiązuje tryb pilny uchwalania przez Komisję aktów delegowanych pod warunkiem, że stosowny przepis upoważniający znajduje się w akcie podstawowym. Następnie Parlament Europejski i Rada Unii Europejskiej, działając niezależnie od siebie, zapoznają się z projektem i mają zasadniczo dwa miesiące na wyrażenie sprzeciwu, z możliwością przedłużenia tego terminu o kolejne dwa miesiące. Do automatycznego przedłużenia terminu wystarcza wszelako wniosek jednej z tych instytucji. Jeżeli Parlament Europejski lub Rada Unii Europejskiej skorzystają z prawa do sprzeciwu, akt delegowany nie może wejść w życie. Przyczyny wyrażenia sprzeciwu winny być podane w uzasadnieniu ${ }^{74}$. Jeżeli jednak ani Parlament Europejski, ani Rada Unii Europejskiej nie wyrażą sprzeciwu, lub poinformują Komisję Europejską, że nie zamierzają takiego sprzeciwu wyrażać, akt delegowany wchodzi w życie. Obie wspomniane instytucje mogą także odwołać delegację przekazaną w akcie ustawodawczym. Ponadto w skrajnych przypadkach mają one prawo do całkowitego odwołania uprawnień Komisji Europejskiej do wydawania aktów delegowanych ${ }^{75}$.

\section{II.2. Akty wykonawcze}

Również w lipcu 2009 r. rozpoczęły się prace przygotowawcze do implementacji przepisów traktatu lizbońskiego, dotyczących aktów wykonawczych, czyli aktów powierzających uprawnienia wykonawcze Komisji Europejskiej lub Radzie Unii Europejskiej. Jednak ta ostatnia mogła je wydawać jedynie $w$ należycie uzasadnionych przypadkach

73 Council of the European Union, Common Understanding on delegated acts, 8640/11, Brussels, 4 IV 2011, s. 1-8.

74 Wtedy Komisja miała dwie możliwości: albo przygotować nowy akt delegowany, uwzględniając przyczyny sprzeciwu, albo nie podejmować prac nad nowym aktem.

75 Council of the European Union, Common Understanding..., s. 1-8; Informacja dla Sejmu i Senatu Rzeczypospolitej Polskiej o udziale Rzeczypospolitej Polskiej w pracach Unii Europejskiej w okresie lipiec-grudzień $2010 \mathrm{r}$. (podczas prezydencji belgijskiej), Warszawa 2011, s. 7, 9-10. Szerzej na temat implementacji przepisów traktatu lizbońskiego, dotyczących aktów delegowanych por.: J. Barcz, Traktat z Lizbony. Wybrane aspekty prawne dziatań implementacyjnych, Warszawa 2012, s. 218-241, Monografie-LexiNexis Polska. 
oraz w przypadkach określonych $w$ artykutach 24 i 26 Traktatu o Unii Europejskiej, dotyczących wspólnej polityki zagranicznej i bezpieczeństwa (art. 291 ust. 2 TFUE). W odróżnieniu od aktów delegowanych, uprawnienia do uchwalania aktów wykonawczych przez Komisję Europejską lub Radę Unii Europejskiej mogły być im przekazywane na podstawie „prawnie wiążących aktów Unii”, czyli zarówno aktów ustawodawczych, jak i nieustawodawczych (art. 291 ust. 1 TFUE) ${ }^{76}$.

O ile przepisy dotyczące aktów delegowanych, zawarte w art. 290 TFUE i przewidujące kontrolę Parlamentu Europejskiego i Rady Unii Europejskiej nad wykonywaniem przez Komisję Europejską jej uprawnień, obowiązywały bezpośrednio i nie wymagały przyjęcia żadnych dodatkowych regulacji prawnych w celu ich zastosowania, o tyle postanowienia odnoszące się do aktów wykonawczych, zawarte w art. 291 TFUE, zakładające kontrolę państw członkowskich nad realizacją uprawnień wykonawczych przez Komisję Europejską, wymagały ustanowienia mechanizmu takiej kontroli, a w ślad za tym przyjęcia przez Parlament Europejski i Radę Unii Europejskiej odpowiednich regulacji prawnych.

Przed wejściem w życie traktatu lizbońskiego system przekazywania Komisji Europejskiej uprawnień wykonawczych funkcjonował zasadniczo w ramach tzw. procedury komitetowej (komitologii) ${ }^{77}$. Status traktatowy nadał tej procedurze Jednolity Akt Europejski z 17/28 lutego 1986 r. ${ }^{78}$ Umocnienie kompetencji wykonawczych Komisji na mocy tegoż traktatu rewizyjnego polegało na tym, że przekazywanie jej uprawnień wykonawczych przez Radę przestało być fakultatywne i stało się obowiązkowe. Z drugiej strony jednak Rada Ministrów nadal zachowała pewną kontrolę nad działalnością wykonawczą Komisji. 13 lipca 1987 r. przyjęła ona decyzję ustanawiającą trzy rodzaje komitetów i procedur dla realizacji uprawnień wykonawczych przez Komisję. Były to: komitet i procedura doradcza, komitet i procedura zarządzająca, a także komitet i procedura regulacyjna. W skład komitetów wchodzili przedstawiciele rządów państw członkowskich (po jednym z każdego państwa), przy czym na ich czele, jako przewodniczący, stali każdorazowo reprezentanci Komisji. Komitet doradczy w najmniejszym stopniu ograniczał uprawnienia wykonawcze Komisji Europejskiej, ponieważ jego opinie, uchwalane zwykłą większością głosów, nie były dla niej wiążące. Komitet zarządzający pozwalał na większą ingerencję w działalność wykonawczą Komisji, albowiem mogła ona uchwalić akt wykonawczy tylko wtedy, gdy komitet, stanowiąc większością kwalifikowaną, wydał opinię pozytywną lub nie wyraził swojej opinii. Natomiast komitet regulacyjny w największym stopniu ograniczał jej uprawnienia wykonawcze, gdyż

76 Art. 291 ust. 1-2 TFUE.

77 Rada Ministrów rozpoczęla delegowanie na Komisję uprawnień wykonawczych już w latach 60. XX w., najpierw we wspólnej polityce rolnej, a następnie od 1968 r. również w dziedzinie prawa celnego. Jednak przekazywanie przez Radę Ministrów uprawnień wykonawczych Komisji nie było obowiązkowe. W ówczesnej procedurze komitetowej Komisja była zobowiązana do konsultowania swoich decyzji wykonawczych z tzw. komitetem zarządzającym (stąd nazwa procedury). Jeżeli komitet wydał negatywną opinię na temat projektu decyzji Komisji, to wówczas Rada Ministrów, stanowiąc większością kwalifikowaną, mogła go zmienić. Por.: J.J. Węc, Spór o ksztatt ustrojowy..., s. 187-188.

78 Art. 10 JAE. 
mogła ona uchwalać tylko te akty wykonawcze, które uzyskały jego pozytywną opinię, wydaną kwalifikowaną większością głosów. Zarówno w procedurze zarządzającej (w przypadku negatywnej opinii komitetu), jak i procedurze regulacyjnej (w przypadku negatywnej opinii komitetu lub jej braku) Rada Unii Europejskiej, stanowiąc większością kwalifikowaną, miała możliwość samodzielnego uchwalenia aktów wykonaw$\operatorname{czych}^{79}$.

Analizowane przepisy zostały zmienione na mocy decyzji Rady Unii Europejskiej z 17 lipca 2006 r. Rozszerzała ona system komitologiczny przez ustanowienie procedury i komitetu regulacji połączonej z kontrolą sprawowaną przez Parlament Europejski i Radę Unii Europejskiej. W porównaniu z dotychczasowymi przepisami komitet ten w największym zakresie ograniczał uprawnienia wykonawcze Komisji Europejskiej, ponieważ obaj unijni prawodawcy, czyli Rada Unii Europejskiej (większością kwalifikowaną) i Parlament Europejski (większością głosów swoich członków), mieli prawo do przeprowadzania kontroli przed przyjęciem aktów wykonawczych przez Komisję Europejską, w tym prawo do wyrażania sprzeciwu wobec projektu Komisji nawet w sytuacji, gdy komitet wydał na jego temat pozytywną opinię. Jeżeli natomiast komitet wyraził opinię negatywną lub w ogóle jej nie wydał, obaj unijni prawodawcy mogli się sprzeciwić projektowi Komisji, przy czym pozycja Parlamentu Europejskiego była w tym przypadku słabsza aniżeli rola Rady Unii Europejskiej. Ta ostatnia mogła bowiem wyrazić swój sprzeciw już na początku procedury, zaś Parlament dopiero w sytuacji, gdy Rada zgodziła się na przyjęcie projektu lub w ogóle nie wyraziła żadnej opinii ${ }^{80}$.

Prace przygotowawcze do implementacji przepisów art. 291 ust. 1-4 TFUE były prowadzone na szczeblu COREPER I z udziałem przedstawicieli Komisji Europejskiej

79 Poza tymi trzema procedurami istniała jeszcze, rzadko stosowana, procedura w sprawie środków ochronnych. Odnosiła się ona do aktów podstawowych, które przyznawały Komisji uprawnienia do uchwalania w określonych sytuacjach środków ochronnych (np. środków antydumpingowych). Jeżeli Komisja taki środek przyjęła, musiała powiadomić o tym Radę i państwa członkowskie (jeszcze przed podjęciem decyzji Komisja mogła przeprowadzić konsultacje z państwami członkowskimi). Następnie Rada mogła podjąć inną decyzję w terminie określonym w akcie podstawowym (wariant a) lub mogła potwierdzić, zmienić albo uchylić decyzję przyjętą przez Komisję. Jeśli Rada nie podjęła decyzji w terminie określonym w akcie podstawowym, decyzję Komisji uważało się za uchyloną (wariant b), por.: Council Decision of 13 July 1987 laying down the procedures for the exercise of implementing powers conferred on the Commission (87/373/EEC), O.J. EC 1987, L 197, s. 33-35. Szerzej na temat trzech głównych procedur komitologicznych por.: J.J. Węc, Spór o ksztatt ustrojowy..., s. 188-189. Deklaracja nr 31 załączona do Aktu Końcowego konferencji międzyrządowej z lat 1996-1997 wezwała Komisję Europejską do przedłożenia Radzie Unii Europejskiej projektu zmiany decyzji z 13 lipca 1987 r. W celu uniknięcia pomyłek postanowiono jednak nie zmieniać tej decyzji, ale zastąpić ją inną. W efekcie 28 czerwca 1999 r. Rada Unii Europejskiej przyjęła nową decyzję komitologiczną, która utrzymywała wszystkie dotychczasowe procedury i komitety, ale także upraszczała warunki wykonywania przez Komisję jej uprawnień wykonawczych oraz nieznacznie wzmacniała kompetencje Parlamentu Europejskiego. Miał on być odtąd regularnie informowany przez Komisję o działaniach komitetów. Por.: Council Decision of 28 June 1999 laying down the procedures for the exercise of implementing powers conferred on the Commission (1999/468/EC), O.J. EC 1999, L 184, s. 23-26.

Decyzja Rady z dnia 17 lipca 2006 r. zmieniająca decyzje 1999/468/WE ustanawiająca warunki wykonywania uprawnień wykonawczych przyznanych Komisji (2006/512/WE), Dz. U. UE 2006, L 200, s. 11-13. 
i Rady Unii Europejskiej ${ }^{81}$. Prezydencja została upoważniona do uzgodnienia z Parlamentem Europejskim i Komisją Europejską treści deklaracji o wykonywaniu przepisów decyzji Rady z 28 czerwca 1999 r. do czasu przyjęcia nowego rozporządzenia dotyczącego komitologii ${ }^{22} .11$ grudnia 2009 r. Rada Unii Europejskiej przyjęła stosowną deklarację. Stanowiła ona, że wspomniana wyżej decyzja winna obowiązywać aż do momentu uchwalenia nowego rozporządzenia, określającego przepisy i zasady ogólne dotyczące trybu kontroli przez państwa członkowskie realizacji uprawnień wykonawczych przez Komisję Europejską ${ }^{83}$.

9 marca 2010 r. Komisja Europejska opublikowała wniosek ustawodawczy w sprawie rozporządzenia Parlamentu Europejskiego i Rady Unii Europejskiej, ustanawiającego przepisy i zasady ogólne dotyczące trybu kontroli przez państwa członkowskie wykonywania uprawnień wykonawczych przez Komisję $e^{84}$. Następnie prace nad kształtem tego nowego aktu prawnego były prowadzone na forum Grupy Przyjaciół Prezydencji (Radców Prawnych), ale przebiegały w atmosferze sporów między poszczególnymi delegacjami rządowymi, przy czym przedmiotem najpoważniejszych kontrowersji była rola wspólnej polityki handlowej w obowiązującym systemie komitologicznym ${ }^{85}$.

Kompromis w sprawie nowego rozporządzenia udało się osiągnąć 1 grudnia 2010 r., kiedy to COREPER I przyjął tekst aktu prawnego w brzmieniu uzgodnionym z Parlamentem Europejskim. Umożliwiło to uchwalenie go w pierwszym czytaniu. 16 lutego 2011 r. Rada Unii Europejskiej i Parlament Europejski przyjęły nowe rozporządzenie ustanawiające przepisy i zasady ogólne dotyczące trybu kontroli przez państwa członkowskie wykonywania uprawnień wykonawczych przez Komisję Europejską. Na jego mocy liczba procedur komitologicznych została zredukowana do dwóch, tzn. procedury doradczej, odpowiadającej dotychczasowej procedurze doradczej, a także procedury sprawdzającej (egzaminacyjnej), która zastąpiła dotychczasowe procedury: zarządzania i regulacyjną. W procedurze doradczej opinia komitetu jest podejmowana zwykłą większością głosów i jest niewiążąca dla Komisji Europejskiej (art. 4 ust. 1-2 rozporządzenia $)^{86}$. Natomiast w procedurze sprawdzającej w przypadku negatywnej opinii komitetu (wyrażonej większością kwalifikowaną) Komisja nie przyjmuje projektu aktu wykonawczego. Jednak jeśli przyjęcie aktu uważa się za niezbędne, Komisja może w ciągu dwóch miesięcy przedłożyć komitetowi jego zmienioną wersję albo w ciągu jednego miesiąca przesłać go do komitetu odwoławczego (apelacyjnego) (art. 5 ust. 3 rozporządzenia). Je-

${ }^{81} \quad$ Prezydencja do Rady i Rady Europejskiej. Sprawozdanie z postępu prac przygotowawczych..., s. 5.

82 Deklaracja ta nie mogła jednak przesądzać stanowiska Rady, por.: tamże.

83 Informacja dla Sejmu i Senatu o udziale Rzeczypospolitej Polskiej w pracach Unii Europejskiej w okresie styczeń-czerwiec 2010 roku (podczas prezydencji hiszpañskiej), s. 6.

84 Komisja Europejska, Wniosek. Rozporzadzenie Parlamentu Europejskiego i Rady ustanawiajace przepisy $i$ zasady ogólne dotyczące trybu kontroli przez państwa cztonkowskie wykonywania uprawnień wykonawczych przez Komisje, COM(2010) 83 wersja ostateczna, Bruksela, 9 III 2010, s. 1-13.

85 Informacja dla Sejmu i Senatu o udziale Rzeczypospolitej Polskiej w pracach Unii Europejskiej w okresie styczeń-czerwiec 2010 roku (podczas prezydencji hiszpañskiej), s. 6.

86 Choć z drugiej strony jest ona jak dotychczas zobowiązana do uwzględniania w jak największym stopniu uwag przedstawicieli państw członkowskich zasiadających w komitecie. 
żeli w procedurze sprawdzającej komitet nie przyjmie opinii (brak większości kwalifikowanej do uchwalenia opinii pozytywnej czy negatywnej), Komisja posiada dwa możliwe rozwiązania: albo przyjmuje akt wykonawczy, albo go nie uchwala i przedstawia komitetowi jego zmienioną wersję. $Z$ tej pierwszej możliwości Komisja nie może jednak skorzystać w trzech przypadkach, po pierwsze, gdy projekt aktu dotyczy opodatkowania, usług finansowych, ochrony zdrowia lub bezpieczeństwa ludzi, zwierząt i roślin, lub ostatecznych wielostronnych środków ochronnych; po drugie, gdy zabrania tego akt podstawowy; po trzecie, gdy komitet sprawdzający wyraził sprzeciw wobec przyjęcia aktu zwykłą większością głosów. W każdym z tych trzech przypadków, jeżeli przyjęcie aktu uważa się za nieodzowne, Komisja może w ciągu dwóch miesięcy przedłożyć komitetowi sprawdzającemu jego zmienioną wersję lub w ciągu jednego miesiąca przedłożyć projekt komitetowi odwoławczemu (art. 5 ust. 4 rozporządzenia). Zarówno w sytuacji przewidzianej w art. 5 ust. 3 , jak i art. 5 ust. 4 rozporządzenia komitet apelacyjny wydaje ostateczną opinię na temat projektu aktu wykonawczego, stanowiąc większością kwalifikowaną. Jeżeli komitet przyjmie pozytywną opinię lub w ogóle jej nie wyda, Komisja Europejska uchwala projekt aktu wykonawczego. Natomiast w przypadku negatywnej opinii komitetu Komisja musi rozpocząć na nowo prace nad projektem (art. 6 rozporządzenia) ${ }^{87}$.

$\mathrm{Na}$ mocy analizowanego rozporządzenia uprawnienia kontrolne powierzone zostały rządom państw członkowskich, reprezentowanym w komitetach przez ekspertów, natomiast sama Rada Unii Europejskiej, inaczej niż dotychczas, została ich pozbawiona. Nie ma ona już bowiem możliwości rozpatrywania kontrowersyjnych propozycji Komisji. W zamian za to rozporządzenie wprowadziło mechanizm dodatkowej politycznej kontroli rządów państw członkowskich nad działaniami Komisji Europejskiej w postaci komitetu odwoławczego. Podejmuje on ostateczne decyzje wobec tych propozycji Komisji Europejskiej, które w ramach procedury sprawdzającej napotkały sprzeciw państw, a mimo to Komisja dąży do ich przyjęcia. W niektórych przypadkach dotyczy to również projektów, wobec których komitet sprawdzający nie wydał swojej opinii ${ }^{88}$. Rozporządzenie Rady Unii Europejskiej i Parlamentu Europejskiego z 16 lutego 2011 r. zniosło wprawdzie procedurę regulacyjną połączoną z kontrolą, ale ustanowiło także okres przejściowy niezbędny dla jej dostosowania do nowego stanu prawnego. Procedura ta będzie istniała nadal w odniesieniu do aktów, które się do niej odwołują, ale stopniowo będzie ona zastępowana systemem aktów delegowanych. Komisja Europejska została bowiem zobowiązana do przedstawienia do końca $2014 \mathrm{r}$. nowych propozycji mających na celu pełne dostosowanie wspomnianych aktów do przepisów art. 290 TFUE ${ }^{89}$.

Rozporzadzenie Parlamentu Europejskiego i Rady (UE) NR 182/2011 z dnia 16 lutego 2011 r. ustanawiające przepisy i zasady ogólne dotyczace trybu kontroli przez państwa cztonkowskie wykonywania uprawnień wykonawczych przez Komisje, Dz. U. UE 2011, L 55, s. 13-18.

88 Tamże. Por. też: Informacja dla Sejmu i Senatu o udziale Rzeczypospolitej Polskiej w pracach Unii Europejskiej w okresie styczeń-czerwiec 2011 roku (podczas prezydencji wegierskiej), Warszawa 2011, s. 7, 10-11. Szerzej na temat nowego systemu komitologicznego por.: J. Barcz, Traktat z Lizbony..., s. 244-264.

89 Informacja dla Sejmu i Senatu o udziale Rzeczypospolitej Polskiej w pracach Unii Europejskiej w okresie styczeń-czerwiec 2011 roku (podczas prezydencji wegierskiej), s. 11. Por. też: J. Barcz, Traktat z Lizbony..., s. 243-244. 


\section{ZASADY DEMOKRATYCZNE I AKSJOLOGIA UNII EUROPEJSKIEJ}

\section{III.1. Inicjatywa obywatelska}

Traktat lizboński ustanawia po raz pierwszy instytucję obywatelskiej inicjatywy ustawodawczej, co ma niezwykle istotne znaczenie dla wzmocnienia zarówno legitymacji demokratycznej Unii Europejskiej, jak też rozszerzenia zasady demokracji uczestniczącej w Unii. W doktrynie zwraca się uwagę na fakt, że instytucja inicjatywy obywatelskiej przypomina prawo do tzw. pośredniej inicjatywy legislacyjnej, jakim od początku dysponowała Rada Ministrów Wspólnot Europejskich, a następnie Rada Unii Europejskiej (art. 26 TEWWS, art. 152 TEWG [art. 208 TWE], art. 122 TEWEA), zaś od momentu wejścia w życie Traktatu z Maastricht posiadał ją także Parlament Europejski (art. 192 TWE). Obecnie Rada Unii Europejskiej może występować z pośrednią inicjatywą ustawodawczą na mocy art. 241 TFUE, zaś Parlament Europejski na podstawie art. 225 TFUE ${ }^{90}$.

Zgodnie z przepisami art. 11 ust. 4 TUE w wersji traktatu lizbońskiego z inicjatywą obywatelską musi wystąpić co najmniej milion osób, mających obywatelstwo znacznej liczby państw członkowskich. Winna ona dotyczyć spraw, w których - zdaniem obywateli - stosowanie traktatów wymaga uchwalenia aktu prawnego Unii Europejskiej. Wniosek w tej sprawie ma być kierowany do Komisji Europejskiej, która następnie w ramach swoich uprawnień może wystąpić z inicjatywą ustawodawczą. Z kolei art. 24 TFUE akapit pierwszy stanowi, że przepisy dotyczące procedur i warunków wymaganych do przedstawienia inicjatywy obywatelskiej (w tym minimalnej liczby państw członkowskich, z których muszą pochodzić obywatele, występujący z taką inicjatywą) winny być skodyfikowane w rozporządzeniu Parlamentu Europejskiego i Rady Unii Europejskiej zgodnie ze zwykłą procedurą ustawodawczą ${ }^{91}$.

W ramach procesu implementacji postanowień art. 11 ust. 4 TUE oraz art. 24 TFUE Komisja Europejska wydała 11 listopada 2009 r. Zieloną Księgę w sprawie inicjatywy obywatelskiej. Jej celem było zebranie opinii wszystkich zainteresowanych stron na temat kształtu przyszłego rozporządzenia ${ }^{92}$. Dwa miesiące po zakończeniu konsultacji społecznych, 31 marca 2010 r., Komisja przedstawiła projekt rozporządzenia Parlamentu Europejskiego i Rady Unii Europejskiej w sprawie inicjatywy obywatelskiej ${ }^{93}$. Po przeprowadzeniu debaty orientacyjnej i przyjęciu podejścia ogólnego 14 czerwca 2010 r. Rada podjęła decyzję o rozpoczęciu negocjacji z Parlamentem Euro-

90 J.J. Węc, Spór o ksztatt ustrojowy..., s. 44, 100. Szerzej na ten temat por.: J. Barcz, Traktat z Lizbony. Wybrane aspekty prawne..., s. 195-197.

91 Art. 11 ust. 4 TUE, art. 24 TFUE.

92 Prezydencja do Rady i Rady Europejskiej. Sprawozdanie z postęu prac przygotowawczych..., s. 5. Szerzej na ten temat por.: A.A. Capik, A. Gniewek, Wprowadzenie do prawa europejskiej inicjatywy obywatelskiej, Luksemburg, 4 IV 2012, s. 42-46, [online] http://www.euroinfo.krakow.pl/upload/Europejska\%20inicjatywa\%20obywatelska\%20-\%20B.\%20Capik\%20A.\%20Gniewek.pdf, 15 V 2015.

93 Komisja Europejska, Wniosek. Rozporzadzenie Parlamentu Europejskiego i Rady w sprawie inicjatywy obywatelskiej, COM(2010) 119 wersja ostateczna, Bruksela, 31 III 2010, s. 1-34. 
pejskim w celu uchwalenia rozporządzenia w pierwszym czytaniu ${ }^{94}$. 14 lutego $2011 \mathrm{r}$. Rada Unii Europejskiej przyjęła rozporządzenie w pierwszym czytaniu, zaś dwa dni później Parlament Europejski i Rada ostatecznie go zatwierdziły 95 .

Rozporządzenie w sprawie inicjatywy obywatelskiej z 16 lutego 2011 r. stanowi, że inicjatywę obywatelską musi zgłosić Komisji Europejskiej co najmniej jeden milion obywateli Unii Europejskiej, pochodzących z co najmniej 1/4 wszystkich państw członkowskich. Dla każdego z państw ustalona została minimalna liczba sygnatariuszy, odpowiadająca liczbie wybranych tam posłów do Parlamentu Europejskiego, pomnożonej przez 750. W efekcie minimalna liczba sygnatariuszy wahała się w poszczególnych państwach członkowskich od 74250 (Niemcy) do 3750 (Malta), natomiast w Polsce wyniosła $37500^{96}$.

Parlamentowi Europejskiemu nie udało się w rokowaniach legislacyjnych z Radą Unii Europejskiej przeforsować stanowiska, zgłoszonego przez Komisję Spraw Konstytucyjnych, zgodnie z którym próg minimalnej liczby państw, spośród których miałby pochodzić co najmniej jeden milion podpisów, winien wynosić $1 / 5$, zaś wiek sygnatariuszy inicjatywy obywatelskiej (czyli obywateli Unii, którzy wyrazili dla niej poparcie przez wypełnienie stosownej deklaracji) powinien być zharmonizowany na poziomie Unii Europejskiej i obniżony do 16 lat. Mimo to ostateczny kompromis w sprawie progu minimalnej liczby państw opierał się na wcześniejszej propozycji Parlamentu Europejskiego, zawartej już w jego rezolucji z 7 maja 2009 r. ${ }^{97} \mathrm{~W}$ sprawie wieku uprawniającego do poparcia inicjatywy przyjęto natomiast porozumienie zgodne ze stanowiskiem Rady Unii Europejskiej. Zrezygnowano z zamysłu jego harmonizacji na poziomie Unii Europejskiej oraz ustalono, że wiek ten winien być dostosowany do krajowych przepisów o prawie wyborczym. Z drugiej strony jednak zgodnie z intencją Parlamentu Europejskiego postanowiono, że komitet obywatelski, odpowiedzialny za przygotowanie inicjatywy obywatelskiej i przedłożenie jej Komisji Europejskiej, winien się składać z co najmniej siedmiu obywateli Unii, reprezentujących co najmniej siedem państw członkowskich. Ma on także czuwać nad procesem zbierania poparcia dla inicjatywy obywatelskiej. Natomiast Komisja Europejska, po dwóch miesiącach od przedłożenia jej przez

94 Posiedzenie Rady do Spraw Ogólnych w dniu 14 czerwca 2010 r. Komunikat prasowy, 11021/10, Bruksela, 14 VI 2010, s. 6. Debata orientacyjna to dyskusja w Radzie nad projektem aktu prawnego Komisji, niewymagająca liczenia głosów. Ogólne podejście to wstępne porozumienie uzgadniane w ramach Rady w sprawie kluczowych przepisów projektu aktu prawnego Komisji w oczekiwaniu na głosowanie w Parlamencie. Por.: Council of the European Union, Terminology to be used in Council and COREPER agendas for legislative items under the Ordinary Legislative Procedure (OLP), 5084/12, Brussels, 13 I 2012, s. 1-6.

95 Szerzej na ten temat por.: A.A. Capik, A. Gniewek, Wprowadzenie do prawa..., s. 48-52.

96 Rozporządzenie Parlamentu Europejskiego i Rady (UE) Nr 211/2011 z dnia 16 lutego $2011 \mathrm{r}$. w sprawie inicjatywy obywatelskiej, Dz. U. UE 2011, L 65, s. 1-10 (Załącznik I).

97 Rezolucja Parlamentu Europejskiego z 7 maja 2009 r. wzywajaca Komisje do sporzadzenia wniosku w sprawie rozporzadzenia Parlamentu Europejskiego $i$ Rady $w$ sprawie realizacji inicjatywy obywatelskiej. Zatacznik I, (2008/2169(INI)), P6_TA (2009)0389, s. 6. Komisja Europejska w swoim wniosku ustawodawczym z 31 marca 2010 r. zaproponowała przykładowo znacznie wyższy próg 1/3 państw członkowskich. Por.: Komisja Europejska, Wniosek. Rozporządzenie Parlamentu Europejskiego i Rady w sprawie inicjatywy obywatelskiej, $\operatorname{COM}(2010) 119$ wersja ostateczna, s. 5. 
tenże komitet projektu inicjatywy, powinna wyrazić opinię, czy projekt spełnia przesłanki europejskiej inicjatywy obywatelskiej, określone w analizowanym rozporządzeniu. W przypadku pozytywnej odpowiedzi Komisja jest zobowiązana do zarejestrowania inicjatywy na stronie internetowej, zaś proces zbierania wymaganego przez art. 11 ust. 4 TUE jednego miliona podpisów winien trwać nie dłużej niż dwanaście miesięcy (zgodnie z projektem rozporządzenia Komisjii) ${ }^{98}$.

Postanowienia rozporządzenia $\mathrm{w}$ sprawie inicjatywy obywatelskiej mogły być stosowane od 1 kwietnia 2012 r. Rządy państw członkowskich zostały zobowiązane, aby do tego czasu dostosować przepisy krajowe do jego wymogów, wskazując Komisji Europejskiej organy odpowiedzialne za wydawanie certyfikatów potwierdzających liczbę ważnych deklaracji poparcia zebranych w danym państwie członkowskim oraz organy wydające certyfikaty o zgodności systemu zbierania deklaracji on-line z postanowieniami rozporządzenia.

Przyjęta w rozporządzeniu z 16 lutego 2011 r. liczba posłów odpowiadała podziałowi mandatów w Parlamencie Europejskim sprzed wejścia w życie znowelizowanego protokołu nr $36 \mathrm{w}$ sprawie postanowień przejściowych ${ }^{99}$. Gdy 1 grudnia 2011 r. wszedł on w życie, dwanaście państw członkowskich uzyskało osiemnaście dodatkowych mandatów do Parlamentu Europejskiego do końca kadencji 2009-2014. W ślad za tym zmianie uległa także minimalna liczba sygnatariuszy przypadająca na te właśnie państwa. Odtąd liczba ta wahała się od 74250 (Niemcy) do 4500 (Malta, Cypr, Luksemburg i Estonia), zaś w Polsce wyniosła $38250^{100}$. Z kolei na mocy wspomnianej wyżej decyzji Rady Europejskiej z 28 czerwca 2013 r., ustanawiającej skład Parlamentu Europejskiego na kadencję 2014-2019, minimalna liczba sygnatariuszy waha się w poszczególnych państwach członkowskich od 72000 (Niemcy) do 3750 (Malta, Cypr, Luksemburg i Estonia). W Polsce wynosi ona 38250 osób ${ }^{101}$.

\section{III.2. Przystąpienie Unii Europejskiej do Europejskiej Konwencji o Ochronie Praw Człowieka i Podstawowych Wolności Rady Europy}

Traktat lizboński, wprowadzając zmiany do TUE, stworzył po raz pierwszy podstawę prawną oraz zobowiązał Unię Europejską do przystąpienia do Europejskiej Konwencji o Ochronie Praw Człowieka i Podstawowych Wolności (EKPCz) Rady Europy

98 Rozporzadzenie Parlamentu Europejskiego i Rady (UE) Nr 211/2011 z dnia 16 lutego 2011 r...., s. 1-10. Informacja dla Sejmu i Senatu Rzeczypospolitej Polskiej o udziale Rzeczypospolitej Polskiej w pracach Unii Europejskiej w okresie lipiec-grudzień 2010 r. (podczas prezydencji belgijskiej), s. 5-6. Szerzej na temat procedury realizacji inicjatywy obywatelskiej oraz jej oceny por.: J. Barcz, Traktat z Lizbony. Wybrane aspekty prawne..., s. 200-212.

99 Szerzej na temat zmian w liczbie posłów po wejściu w życie protokołu nr 36 por.: J.J. Węc, Traktat Lizboński..., s. 199-200; tenże, Spór o ksztatt ustrojowy..., s. 542-544.

100 Rozporządzenie delegowane Komisji (UE) nr 268/2012 z dnia 25 stycznia 2012 r. zmieniajace zatacznik I do rozporzadzenia Parlamentu Europejskiego i Rady (UE) nr 211/2011 w sprawie inicjatywy obywatelskiej, Dz. U. UE 2012, L 89, s. 1-2.

101 Decyzja Rady Europejskiej z dnia 28 czerwca 2013 r. ustanawiająca sktad Parlamentu Europejskiego, Dz. U. UE 2013, L 181, s. 58. 
z 4 listopada 1950 r. Wszelako przystąpienie Unii do EKPCz nie mogło mieć wpływu na jej kompetencje określone w traktatach (art. 6 ust. 2 TUE) ${ }^{102}$. Protokół nr 8, załączony do TUE i TFUE, wprowadzał dalsze ograniczenia, stanowiąc, że umowa o przystąpieniu do EKPCz winna zapewnić, aby takie przystąpienie nie oddziaływało ani na kompetencje Unii, ani na uprawnienia jej instytucji i szczególną sytuację niektórych państw członkowskich w odniesieniu do EKPCz, zwłaszcza protokołów do niej załączonych, środków podjętych przez państwa członkowskie w drodze odstępstwa od EKPCz, a także zastrzeżeń do EKPCz dokonanych przez niektóre z nich (art. 2 protokołu nr 8$)^{103}$.

Oznaczało to, że przystąpienie Unii do EKPCz nie może wiązać automatycznie państw członkowskich protokołami dodatkowymi do EKPCz, jeżeli nie były one wcześniej ich stronami, a także nie może zmienić w inny sposób zakresu związania tychże państw z EKPCz ${ }^{104}$. Wydaje się, że mimo wspomnianych ograniczeń, już samo stworzenie podstawy prawnej oraz zobowiązanie Unii Europejskiej do przystąpienia do EKPCz winno mieć istotne znaczenie zwłaszcza dla zapewnienia spójności i efektywności europejskiego systemu ochrony praw człowieka, ponieważ będzie ono w istocie oznaczało połączenie obu istniejących do tej pory systemów: konwencyjnego i unijnego ${ }^{105}$.

Po stronie Rady Europy podstawę prawną do akcesji Unii Europejskiej do EKPCz stanowił protokół nr 14 do Konwencji, który został podpisany przez państwa strony 13 maja 2004 r. w Strasburgu, zaś wszedł w życie 1 czerwca 2010 r. Wprowadził on zmianę art. $59 \mathrm{EKPCz}$, umożliwiającą przystąpienie Unii Europejskiej do Konwencji, co było niezbędne, ponieważ dotychczas jej stronami były wyłącznie państwa członkowskie Rady Europy, a nie organizacja międzynarodowa ${ }^{106}$.

Art. 6 ust. 2 TUE nie określa formy prawnej przystąpienia Unii Europejskiej do EKPCz, precyzuje ją natomiast protokół nr 8, stanowiąc, że powinno to nastąpić na podstawie umowy międzynarodowej (art. 1 protokołu $\mathrm{nr} 8$ ) $^{107}$. Ponieważ postanowienia art. 6 ust. 2 TUE nie wskazują również trybu przystąpienia Unii Europejskiej do EKPCz, obowiązuje w tym przypadku ogólna procedura przystępowania Unii do

102 Art. 6 ust. 2 TUE.

103 Protokót dotyczący artykutu 6 ustęp 2 Traktatu o Unii Europejskiej w sprawie przystapienia Unii do Europejskiej Konwencji o Ochronie Praw Cztowieka i Podstawowych Wolności, [w:] Traktat z Lizbony, s. 273. Z kolei deklaracja nr 2 stanowiła, że przystąpienie Unii do EKPCz powinno nastąić w taki sposób, aby można byto zachować szczególny charakter porządku prawnego Unii, por.: Deklaracja odnosząca się do artykutu 6 ustęp 2 Traktatu o Unii Europejskiej, [w:] Traktat z Lizbony, s. 337.

104 A. Wyrozumska, Umocnienie ochrony praw podstawowych, [w:] Traktat z Lizbony. Gtówne reformy ustrojowe Unii Europejskiej, red. nauk. J. Barcz, Warszawa 2008, s. 179-180.

105 Por.: N. Półtorak, Przystapienie do Konwencji o Ochronie Praw Cztowieka i Podstawowych Wolności z perspektywy Unii Europejskiej, [w:] Obywatel w Radzie Europy i Unii Europejskiej. Nowe wyzwania po dwudziestu latach od przystapienia przez Polskę do Konwencji o Ochronie Praw Cztowieka i Podstawowych Wolności, Warszawa 2014, s. 90-91. Por. też: J.J. Węc, Traktat Lizboński..., s. 127-128.

106 Szerzej na ten temat por.: A. Gajda, Przystąpienie Unii Europejskiej do Europejskiej Konwencji o Ochronie Praw Cztowieka i Podstawowych Wolności, „Studia i Prace” (Kwartalnik Kolegium Ekonomiczno-Społecznego SGH) 2013, nr 1, s. 17-18.

107 Protokót dotyczacy artykutu 6 ustęp 2 Traktatu o Unii Europejskiej..., s. 273. 
umów międzynarodowych, określona w art. 218 ust. 1-11 TFUE ${ }^{108}$. Zgodnie z tą procedurą wszystkie najważniejsze decyzje w tym zakresie podejmuje Rada Unii Europejskiej. I tak, decyduje ona o rozpoczęciu rokowań, wydaniu wytycznych negocjacyjnych, mianowaniu negocjatora lub przewodniczącego zespołu negocjatorów, a także o wyznaczeniu specjalnego komitetu, w konsultacji z którym należy prowadzić rokowania. Ponadto przyjmuje ona - każdorazowo na wniosek negocjatora - decyzję upoważniającą do podpisania, a następnie decyzję w sprawie ostatecznego zawarcia umowy międzynarodowej (art. 218 ust. 2-6 TFUE) ${ }^{109}$. Na wszystkich etapach tej procedury dotyczącej zawarcia umowy o przystąpieniu Unii Europejskiej do EKPCz Rada Unii Europejskiej stanowi jednomyślnie (art. 218 ust. 8 TFUE). Decyzja Rady w sprawie zawarcia umowy akcesyjnej wymaga także zgody Parlamentu Europejskiego oraz ratyfikacji przez wszystkie państwa członkowskie, stosownie do postanowień ich prawa krajowego (art. 218 ust. 6, 8 TFUE) ${ }^{110}$.

Wejście w życie decyzji Rady nie przesądza jednak o wejściu w życie samej umowy akcesyjnej. Ta ostatnia musi być bowiem podpisana przez państwa strony $\mathrm{EKPCz}$ i Unię Europejską, ponieważ jest to umowa zawierana pomiędzy tymi podmiotami ${ }^{111}$. Umowa akcesyjna będzie zatem wymagała po stronie Unii Europejskiej wejścia w życie wspomnianej decyzji Rady Unii Europejskiej w wyniku jej ratyfikacji przez wszystkie państwa członkowskie, zaś po stronie Rady Europy jej zatwierdzenia przez 47 państw stron EKPCz zgodnie z ich wymogami konstytucyjnymi ${ }^{112}$.

4 czerwca 2010 r. Rada Unii Europejskiej, działając na podstawie art. 218 ust. 2 TFUE, uchwaliła mandat i wytyczne negocjacyjne. Komisja Europejska została wyznaczona jako negocjator umowy akcesyjnej. 7 lipca 2010 r. rozpoczęła ona w imieniu Unii negocjacje z Komitetem Sterującym Rady Europy ds. Praw Człowieka (Comité directeur pour les droits de l'Homme - CDDH). Ich celem miało być opracowanie projektu umowy akcesyjnej. Zajęła się tym specjalnie powołana grupa ekspertów obu organizacji złożona z czternastu osób, w tym siedmiu z państw nienależących do Unii, reprezentujących Komitet Sterujący Rady Europy ds. Praw Człowieka, oraz siedmiu z państw członkowskich Unii Europejskiej (tzw. grupa ekspertów CDDH-UE) ${ }^{113}$.

\footnotetext{
108 Art. 218 ust. 1-11 TFUE.
}

109 Szerzej na ten temat por.: J. Barcz, Traktat z Lizbony. Wybrane aspekty prawne..., s. 301-304; C. Herma, Likwidacja „struktury filarowej" Unii - podmiotowośc prawnomiędzynarodowa UE oraz reforma systemu aktów prawa pierwotnego i wtórnego, [w:] Traktat z Lizbony. Gtówne reformy ustrojowe..., s. 125-126. Pojęcie „zawarcie umowy międzynarodowej” jest szersze od określenia „podpisanie umowy”, ponieważ obejmuje ono rozpoczęcie i prowadzenie negocjacji, opracowanie projektu umowy, przyjęcie tekstu umowy, wyrażenie zgody na podpisanie umowy, a także samo jej podpisanie (albo zawarcie jej w inny sposób).

110 Art. 218 ust. 1-8 TFUE.

111 Jej sygnatariuszami będą Unia Europejska, a nie poszczególne państwa członkowskie Unii, oraz 47 państw stron EKPCz, a nie 47 państw członkowskich Rady Europy.

112 Szerzej na ten temat por.: J. Barcz, Traktat z Lizbony. Wybrane aspekty prawne..., s. 349-351; A. Gajda, Przystapienie Unii Europejskiej..., s. 19-20.

113 Rada Unii Europejskiej, Nota prezydencji do COREPER II/Rady ds. Wymiaru Sprawiedliwości i Spraw 
Ponadto już w grudniu 2009 r., wkrótce po wejściu w życie traktatu lizbońskiego, Rada Unii Europejskiej na mocy art. 218 ust. 4 TFUE powołała Grupę Roboczą ds. Praw Podstawowych, Praw Obywatelskich i Swobodnego Przepływu Osób (FREMP), nadając jej status specjalnego komitetu ${ }^{114}$. Komisja Europejska regularnie kontaktowała się z nią podczas negocjacji prowadzonych z Komitetem Sterującym Rady Europy ds. Praw Człowieka. Do czerwca 2011 r., po odbyciu ośmiu rund negocjacyjnych, grupa ekspertów CDDH-UE opracowała projekt umowy akcesyjnej, zaś w lipcu tegoż roku przedłożyła go obu stronom ${ }^{115}$.

Projekt nie przewidywał przystąpienia Unii Europejskiej do całego systemu konwencyjnego, lecz jedynie akcesję do EKPCz oraz jej pierwszego i szóstego protokołu (art. 1 ust. 1 projektu umowy), z możliwością przystąpienia w przyszłości do pozostałych. Oznaczało to, iż Unia zamierzała przystąpić tylko do tych protokołów, których stronami były wszystkie jej państwa członkowskie (art. 1 ust. 2 projektu umowy) ${ }^{116}$. Projekt stanowił również, że Unia Europejska będzie miała swojego stałego sędziego w Europejskim Trybunale Praw Człowieka (ETPCz) w Strasburgu, dysponującego takimi samymi uprawnieniami jak sędziowie reprezentujący państwa członkowskie Rady Europy, zaś jego wybór będzie się odbywał zgodnie z procedurą przewidzianą w art. 22 EKPCz dla wyboru sędziów państw stron Konwencji. W celu spełnienia wspomnianych wyżej zastrzeżeń zawartych w protokole nr 8 oraz deklaracji nr 2 uzgodniono dwa kompromisowe rozwiązania. Pierwsze z nich gwarantowało Trybunałowi Sprawiedliwości Unii Europejskiej wyłączną kompetencję do interpretacji prawa unijnego (art. 3 ust. 6 projektu umowy). Natomiast drugie rozwiązanie kompromisowe zakładało ustanowienie tzw. mechanizmu współpozwania (co-respondent mechanism), zastrzeżonego wyłącznie dla Unii Europejskiej i jej państw członkowskich oraz określającego zasady kierowania do ETPCz skarg państw niebędących państwami członkowskimi Unii czy też skarg indywidualnych przeciwko Unii lub jej państwom członkowskim (art. 3 ust. 2-3 projektu umowy ${ }^{117}$.

Wszelako 6 października 2011 r. podczas posiedzenia COREPER II część państw członkowskich Unii Europejskiej zgłosiła zastrzeżenia do treści projektu (głównie

Wewnętrznych. Przystapienie Unii do europejskiej Konwencji o ochronie praw cztowieka i podstawowych wolności, 18117/11, Bruksela, 6 XII 2011, s. 1.

114 Grupa ta powstała z przekształcenia dotychczasowej Grupy Roboczej Ad Hoc ds. Praw Podstawowych i Obywatelstwa. Por.: Rada Unii Europejskiej, Nota Sekretariatu Generalnego do COREPER II/Rady ds. Wymiaru Sprawiedliwości i Spraw Wewnętrznych. Projekt konkluzji Rady w sprawie roli Rady Unii Europejskiej w zapewnianiu skutecznego wprowadzania w zycie Karty praw podstawowych Unii Europejskiej, 6387/11, Bruksela, 11 II 2011, s. 5.

115 Rada Unii Europejskiej, Nota prezydencji do COREPER II/Rady ds. Wymiaru Sprawiedliwości i Spraw Wewnettrznych..., s. 2. Por.: Council of Europe, $8^{\text {th }}$ Working of the CDDH Informal Working Group on the Accession of the European Union to the European Convention on Human Rights (CDDH-UE) with the European Commission, CDDH-UE(2011)11, Strasbourg, 15 VI 2011, s. 1-21.

116 Draft Explanatory Report to the Agreement on the Accession of the European Union to the Convention for the Protection of Human Rights and Fundamental Freedoms, [w: ] Council of Europe, $8^{\text {th }}$ Working of the $C D D H$..., pkt 16.

117 Tamże, pkt 26-28. Por. też: A. Gajda, Przystapienie Unii Europejskiej..., s. 24. 
Wielka Brytania i Francja). W tej sytuacji Komitet Sterujący Rady Europy ds. Praw Człowieka, obradujący w dniach 12-14 października 2011 r., wydał oświadczenie, że Unia Europejska nie jest $w$ stanie przedstawić jednomyślnego stanowiska w sprawie projektu, a następnie poinformował o zaistniałej sytuacji Komitet Ministrów Rady Europy $^{118}$. Tymczasem z inicjatywy polskiej prezydencji w dniach 25 października, 3 listopada, 14-15 listopada, 29 listopada i 12 grudnia 2011 r. na forum FREMP prowadzone były negocjacje pomiędzy państwami członkowskimi Unii Europejskiej w celu uzgodnienia kompromisu politycznego w sprawie projektu umowy akcesyjnej. Przedmiotem dyskusji były m.in. takie kwestie jak: zakres przystąpienia Unii Europejskiej do EKPCz i jego wpływ na kompetencje państw członkowskich, prawo głosu Unii i jej państw członkowskich podczas posiedzeń Komitetu Ministrów Rady Europy poświęconych monitorowaniu wykonywania orzeczeń ETPCz wydawanych przeciwko Unii, a także stosowanie mechanizmu współpozwania ${ }^{119}$. Polskiej prezydencji nie udało się jednak uzgodnić wspólnego stanowiska na forum FREMP. W tej sytuacji postanowiono, że Komisja Europejska przystąpi do negocjowania wszelkich zmian w projekcie umowy akcesyjnej dopiero po osiągnięciu przez państwa członkowskie ostatecznego porozumienia ${ }^{120}$.

Mimo iż także tego nie udało się osiągnąć, w 2012 r. wznowiono rokowania, tym razem w formule Grupy Negocjacyjnej $A d$ Hoc 47+1, obejmującej przedstawicieli Komitetu Sterującego Rady Europy ds. Praw Człowieka oraz Komisji Europejskiej. Po pięciu rundach negocjacji 5 kwietnia 2013 r. udało się uzgodnić Raport końcowy z negocjacji warunków przystąpienia Unii Europejskiej do EKPCz. Składał się on z pakietu pięciu dokumentów: po pierwsze, zrewidowanego projektu umowy akcesyjnej; po drugie, projektu deklaracji, którą Unia Europejska ma złożyć w momencie podpisania umowy akcesyjnej; po trzecie, projektu Reguły dodanej do Reguł Komitetu Ministrów Rady Europy w sprawie nadzorowania wykonywania wyroków oraz warunków polubownego załatwiania spraw, w których Unia Europejska jest stroną; po czwarte, projektu wspólnej deklaracji intencji w sprawie porozumienia między Unią Europejską a państwem nieczłonkowskim Unii; po piąte, projektu raportu wyjaśniającego do umowy akcesyjnej ${ }^{121}$.

Zrewidowany projekt umowy akcesyjnej bazował w dużej mierze na poprzednich, ale także je modyfikował. Zachowane zostały dotychczasowe ustalenia dotyczące mechanizmu współpozwania, pozwalającego w dwóch sytuacjach na przystąpienie - od-

118 Rada Unii Europejskiej, Nota prezydencji do COREPER II/Rady ds. Wymiaru Sprawiedliwości i Spraw Wewnętrznych..., s. 2.

119 Tamże, s. 2-3.

120 Tamże. Podczas posiedzenia Rady ds. Wymiaru Sprawiedliwości i Spraw Wewnętrznych w dniach 13- 14 grudnia 2011 r. polska prezydencja przedłożyła raport z postępu prac, zaś Rada przyjęła go do wiadomości. Por.: Posiedzenie Rady ds. Wymiaru Sprawiedliwości i Spraw Wewnętrznych w dniach 13-14 grudnia 2011 r. Komunikat prasowy, 18498/11, Bruksela, 13-14 XII 2011, s. 38.

121 Por.: Council of Europe, Fifth Negotiation Meeting between the CDDH ad hoc Negotiation Group and the European Commission on the Accession of the European Union to the European Convention on Human Rights. Final Report to the CDDH, 47+1(2013)008, Strasbourg, 5 IV 2013, s. 1-35. 
powiednio Unii Europejskiej lub państwa albo państw członkowskich Unii w charakterze współpozwanego - do postępowania toczącego się przed ETPCz (art. 3 ust. 2-3 projektu umowy ${ }^{122}$. Mechanizm współpozwania miał gwarantować Unii Europejskiej, że ETPCz nie będzie rozstrzygał o podziale kompetencji między Unią a jej państwami członkowskimi. Jeśli skarga była skierowana przeciw Unii Europejskiej lub państwu członkowskiemu, drugi z tych podmiotów mógł uczestniczyć w postępowaniu przed ETPCz w charakterze współpozwanego. Natomiast w przypadku skargi skierowanej przeciwko Unii Europejskiej oraz państwu członkowskiemu status jednego z tych podmiotów mógł być zmodyfikowany na współpozwanego (art. 3 ust. 4 projektu umowy) $)^{123}$.

Podmiotem współpozwanym powinien być zawsze podmiot odpowiadający za podstawę prawną działania, a nie za samo działanie. Jeżeli skarga była skierowana przeciw jednemu lub większej liczbie państw członkowskich, współpozwanym winna być Unia Europejska z powodu niezgodności przepisów prawa pierwotnego lub pochodnego Unii z EKPCz lub jej protokołami (do których Unia przystąpiła), zwłaszcza gdy uniknięcie naruszenia było możliwe wyłącznie w wyniku niedopełnienia zobowiązań wynikających z prawa Unii, tzn. gdy prawo unijne nie pozostawia państwu cztonkowskiemu swobody w zakresie wydawanych krajowych środków implementacyjnych ${ }^{124}$ (art. 3 ust. 2 projektu umowy). Jeśli natomiast skarga była skierowana przeciwko Unii Europejskiej, współpozwanym mogły być państwa członkowskie z powodu niezgodności z EKPCz lub jej protokołami (do których Unia przystąpiła) - przepisów prawa pierwotnego lub jakichkolwiek przepisów mających taką samą moc prawną, zwłaszcza gdy unikniecie naruszenia było możliwe w wyniku niedopełnienia zobowiązań wynikających z prawa Unii (art. 3 ust. 3 projektu umowy). Mechanizm współpozwania winien być stosowany albo przez przyjęcie zaproszenia wystosowanego przez ETPCz, albo w drodze decyzji wydanej przez ETPCz na wniosek Unii Europejskiej lub państw członkowskich (art. 3 ust. 5 projektu umowy). Projekt przewidywał jednak w tej sprawie zasadę fakultatywności, ponieważ nie można było zmusić ani Unii Europejskiej, ani państwa członkowskiego do przystąpienia do takiego postępowania. Współpozwany miał być stroną w postępowaniu, a to oznaczało, że wyrok ETPCz był dla niego wiążący. Jeżeli naruszenie EKPCz lub jej protokołów (do których Unia przystąpiła) zostałoby stwierdzone, pozwany i współpozwany byliby wspólnie odpowiedzialni za to naruszenie, chyba że ETPCz postanowiłby, że do odpowiedzialności należy pociągnąć tylko jednego z nich (art. 3 ust. 7 projektu umowy) $)^{125}$.

W zrewidowanym projekcie umowy akcesyjnej utrzymano również zasadę fakultatywności przystępowania do postępowania przed ETPCz w charakterze współpozwa-

122 Draft revised agreement on the accession of the European Union to the Convention for the Protection of Human Rights and Fundamental Freedoms (Appendix I), [w:] Council of Europe, Fifth Negotiation Meeting..., s. 4-5.

123 Tamże, s. 7.

124 J. Barcz, Traktat z Lizbony. Wybrane aspekty prawne..., s. 356-357.

125 Draft revised agreement..., s. 6-7. 
nego, choć pod presją państw nieczłonkowskich wymuszono na Unii Europejskiej złożenie, zawartej w załączniku, a wspomnianej wyżej, deklaracji, która zobowiązywała ją do „dobrowolnego przystąpienia” do tej procedury, gdy tylko spełnione zostaną przesłanki do współpozwania. Wszelako deklaracja ta nie dotyczyła państw członkowskich Unii. Zachowały one pełną dobrowolność w tym zakresie ${ }^{126}$.

W analizowanym projekcie utrzymano także przepis gwarantujący Trybunałowi Sprawiedliwości Unii Europejskiej pierwszeństwo przed ETPCz w zakresie sprawowania kontroli nad prawem unijnym. W przypadku pozwania państwa członkowskiego i uzyskania przez Unię Europejską statusu współpozwanego postępowanie przed ETPCz miało być zawieszone aż do czasu, gdy Trybunał Sprawiedliwości Unii Europejskiej wyda ocenę na jego temat, ale z drugiej strony ocena taka nie będzie jednak wiążąca dla ETPCz (art. 3 ust. 6 projektu umowy) ${ }^{127}$.

Wynik negocjacji potwierdzał również dotychczasowe ustalenia, że zgodnie z art. 22 EKPCz Unia Europejska będzie miała jednego stałego sędziego w ETPCz, wybieranego większością głosów przez Zgromadzenie Parlamentarne Rady Europy spośród trzech zgłaszanych przez Unię kandydatów. W związku z tym analizowany projekt zapewniał także Parlamentowi Europejskiemu prawo udziału jego 18-osobowej delegacji oraz prawo do głosowania w tych posiedzeniach Zgromadzenia Parlamentarnego, które poświęcone będą wyborowi sędziów do ETPCz (art. 6 ust. 1 projektu umowy) ${ }^{128}$. Parlament Europejski nie uzyskał natomiast nieograniczonego prawa udziału w pracach Zgromadzenia Parlamentarnego. Ponadto zrewidowany projekt umowy akcesyjnej potwierdzał, że Unia Europejska będzie miała jednego przedstawiciela w Komitecie Ministrów Rady Europy, mającego pełne prawo do głosowania w ściśle określonych przypadkach, tzn. gdy Komitet Ministrów będzie wykonywał swoje kompetencje na podstawie art. 26 ust. 2 (zmniejszenie liczby sędziów w izbach), art. 39 ust. 4 (czuwanie nad wykonaniem warunków polubownego załatwienia sprawy), art. 46 ust. 2-5 (wykonanie wyroków ETPCz), art. 47 (wniosek o wydanie opinii doradczej) oraz art. 54 ust. 1 EKPCz (uprawnienia Komitetu Ministrów) (art. 7 ust. 2 projektu umowy) ${ }^{129}$.

4 lipca 2014 r. na podstawie art. 218 ust. 11 TFUE Komisja Europejska zwróciła się do Trybunału Sprawiedliwości Unii Europejskiej z wnioskiem o wydanie opinii na temat zgodności projektu umowy akcesyjnej z prawem Unii Europejskiej. 18 grudnia 2014 r. Trybunał Sprawiedliwości wydał opinię, stanowiącą, że projekt ten jest

126 Draft declaration by the European Union to be made at the time of signature of the Accession Agreement (Appendix II), [w:] Council of Europe, Fifth Negotiation Meeting..., s. 13.

127 Draft revised agreement..., s. 7.

128 Tamże, s. 8.

129 Tamże. Szerzej na temat projektu umowy akcesyjnej z czerwca 2011 r. por.: J. Barcz, Traktat z Lizbony. Wybrane aspekty prawne..., s. 354-362. Por. też: A. Gajda, Przystapienie Unii Europejskiej..., s. 24-32. Szerzej na temat zrewidowanego projektu umowy por.: N. Buchowska, Starania Unii Europejskiej o przystąienie do Konwencji o ochronie praw cztowieka i podstawowych wolności, „Przegląd Zachodni” 2014, nr 4, s. 191-196. Por. też: P. Stawicka, Przystapienie UE do Konwencji o ochronie praw cztowieka i podstawowych wolności, 7 X 2014, s. 3-5, [online] www.psz.pl/121, 15 V 2015. Odmienną ocenę deklaracji Unii Europejskiej, o której mówi załącznik II, por.: N. Półtorak, Przystąpienie do Konwencji..., s. 94-95. 
niezgodny z art. 6 ust. 2 TUE oraz protokołem nr 8 dotyczącym art. 6 ust. 2 TUE w sprawie przystąpienia Unii Europejskiej do $\mathrm{EKPCz}^{130}$. W uzasadnieniu Trybunat Sprawiedliwości sformułował sześć istotnych zastrzeżeń do projektu umowy akcesyjnej.

Po pierwsze, Trybunał stwierdził, że umowa ta nie zapewnia koordynacji między art. 53 EKPCz i art. 53 Karty Praw Podstawowych (KPP) ${ }^{131}$. Przypomniał również, że art. 53 EKPCz zastrzega zasadniczo uprawnienie dla uktadajacych się stron do ustalenia wyższych standardów ochrony praw podstawowych niż te zagwarantowane w Konwen$\mathrm{cji}^{132}$. Z drugiej strony jednak z wykładni art. $53 \mathrm{KPP}$ dokonanej przez Trybunał wyni$\mathrm{ka}$, że stosowanie krajowych standardów ochrony praw podstawowych nie może podważać poziomu ochrony wynikającego $z$ karty praw podstawowych ani pierwszeństwa, jednolitości i skuteczności prawa Unii ${ }^{133}$. Należy zatem zapewnić koordynację pomiędzy postanowieniami art. $53 \mathrm{EKPCz}$ oraz art. $53 \mathrm{KPP}$ w wykładni nadanej przepisom tego ostatniego artykułu przez Trybuna1 ${ }^{134}$. Oznacza to, że w przypadku, gdy prawa uznane w KPP odpowiadają prawom zagwarantowanym w EKPCz, uprawnienie przyznane $w$ art. 53 EKPC państwom cztonkowskim musi pozostać „ograniczone [...] do tego, co konieczne, by uniknać sytuacji, $w$ której poziom ochrony przewidziany w karcie praw podstawowych, jak również pierwszeństwo, jednolitość i skuteczność prawa Unii zostatyby zagrożone $e^{135}$.

Po drugie, Trybunał podkreślił, że projekt nie zawiera żadnych postanowień zapobiegających ryzyku naruszenia zasady wzajemnego zaufania między państwami członkowskimi w prawie Unii Europejskiej ${ }^{136}$. Zdaniem Trybunału, podejście przyjęte w projekcie, polegające na utożsamieniu Unii Europejskiej z państwem (Unia i państwa członkowskie są uznawane za uktadające się strony ${ }^{137}$ ), ignoruje specyficzny charakter Unii, w szczególności zaś nie uwzględnia okoliczności, iż państwa cztonkowskie z racji ich przynależności do Unii zaakceptowaty, że stosunki między nimi w dziedzinach, w których kompetencje zostaty przeniesione z państw cztonkowskich na Unie, sa regulowane prawem Unii z wytaczeniem - o ile prawo Unii tego wymaga - wszelkiego innego prawa ${ }^{138}$. EKPCz pozwala natomiast na to, aby każde państwo członkowskie mogło sprawdzać inne państwo członkowskie Unii Europejskiej w zakresie przestrzegania przez nie praw podstawowych, co może właśnie naruszać zasadę wzajemnego zaufania pomiędzy państwami członkowskimi oraz autonomię prawa Unii ${ }^{139}$.

130 Trybunał Sprawiedliwości Unii Europejskiej, Opinia 2/13 Trybunatu (w petnym sktadzie), Luksemburg, 18 XII 2014, s. 1-51.

131 Motyw 190 Opinii 2/13 Trybunału.

132 Motyw 189 Opinii 2/13 Trybunału.

133 Motyw 188 Opinii 2/13 Trybunału.

134 Motyw 189 Opinii 2/13 Trybunału.

135 Tamże.

136 Motyw 195 Opinii 2/13 Trybunału.

137 Motyw 58 Opinii 2/13 Trybunału.

138 Motyw 193 Opinii 2/13 Trybunału.

139 Motyw 194 Opinii 2/13 Trybunału. 
Po trzecie, Trybunał zwrócił uwagę, że analizowany projekt nie określa relacji pomiędzy mechanizmem ustanowionym na mocy protokołu nr 16 do EKPCz z 2 października 2013 r., upoważniającym sądy krajowe do zwracania się do ETPCz z wnioskami o wydanie opinii doradczej w sprawie wykładni i stosowania EKPCz z jednej strony, a procedurą odesłania prejudycjalnego przewidzianą w art. 267 TFUE z drugiej strony. Może to naruszać autonomię i skuteczność tej procedury ${ }^{140}$. Nie jest bowiem wykluczone, że wniosek o wydanie opinii doradczej złożony na podstawie protokołu nr 16 przez sąd państwa członkowskiego, które przystąpiło do tego protokołu, mógłby uruchomić procedurę wcześniejszego zaangażowania Trybunału [przewidzianą w projekcie umowy akcesyjnej - J.J.W.], tworząc tym samym ryzyko obejścia procedury odesłania prejudycjalnego, przewidzianej w art. 267 TFUE, która [...] stanowi kluczowy element systemu sądowniczego ustanowionego w traktatach ${ }^{141}$.

Po czwarte, Trybunał wskazał, że projekt umowy akcesyjnej może naruszać wyłączną właściwość Trybunału oraz wymogi art. 344 TFUE, ponieważ nie wyklucza on możliwości wnoszenia do ETPCz sporów między państwami członkowskimi lub pomiędzy nimi a Unią Europejską, dotyczących korzystania z EKPCz w ramach przedmiotowego zakresu stosowania prawa Unii ${ }^{142}$. Przepisy zawarte w art. 344 TFUE mają bowiem na celu zachowanie wytacznego charakteru procedur rozstrzygania [...] sporów wewnątrz Unii, w szczególności jurysdykcji Trybunatu w tym względzie, i tym samym sprzeciwiają się wszelkiej uprzedniej lub późniejszej kontroli zewnętrznej ${ }^{143}$. Art. 5 projektu pozostawia natomiast możliwość, iż Unia lub państwa cztonkowskie wniosa do ETPC na podstawie art. 33 EKPC wniosek majacy za przedmiot domniemane naruszenie tej konwencji, popetnione, odpowiednio, przez państwo cztonkowskie lub przez Unię w związku z prawem Unii ${ }^{144}$. Samo istnienie takiej możliwości narusza wymóg ustanowiony $w$ art. 344 $T F U E^{145}$. Jedynie wyraźne wytączenie wtaściwości ETPC wynikajacej z art. 33 EKPC w odniesieniu do sporów między państwami cztonkowskimi lub między nimi a Unia, dotyczacych stosowania EKPC w ramach przedmiotowego zakresu stosowania prawa Unii, bytoby zgodne $z$ art. 344 TFUE $E^{146}$.

Po piąte, Trybunał zauważył, że analizowany projekt nie reguluje zasad funkcjonowania mechanizmu współpozwania i procedury wcześniejszego zaangażowania Trybunału, które to zasady pozwalałyby zachować szczególne cechy Unii i jej prawa. Jeśli chodzi o mechanizm współpozwania, to w ramach kontroli argumentów przedstawionych przez Unię Europejską lub państwa członkowskie we wnioskach o przyznanie statusu współpozwanego - ETPCz może oceniać przepisy prawa Unii, które reguluja rozdziat kompetencji między Unię a jej państwa cztonkowskie oraz kryteria przypi-

140 Motyw 199 Opinii 2/13 Trybunału.
141 Motyw 198 Opinii 2/13 Trybunału.
142 Motyw 214 Opinii 2/13 Trybunału.
143 Motyw 210 Opinii 2/13 Trybunału.
144 Motyw 207 Opinii 2/13 Trybunału.
145 Motyw 208 Opinii 2/13 Trybunału.
${ }_{146}$ Motyw 213 Opinii 2/13 Trybunału. 
sywalności ich aktów lub zaniechań, aby móc wydać ostateczna decyzję $w$ tym wzgledzie, wiążącą zarówno Unię, jak i państwa ${ }^{147}$. Taka kontrola grozi jednak naruszeniem wspomnianego podziału kompetencji ${ }^{148}$. Ponadto art. 3 ust. 7 projektu przewiduje, że w wypadku stwierdzenia naruszenia, w odniesieniu do którego „układająca się strona” jest współpozwaną w postępowaniu, pozwany i współpozwany są solidarnie odpowiedzialni za to naruszenie. Oznacza to, że państwo cztonkowskie może zostać pociagnięte do odpowiedzialności wspólnie z Unia za naruszenie postanowienia EKPC, wobec którego zgłosiło ono wcześniej zastrzeżenie zgodnie z art. 57 tej Konwencji ${ }^{149}$. W świetle powyższych ustaleń Trybunał doszedł do wniosku, że „zasady funkcjonowania mechanizmu wspótpozwania [...] nie gwarantuja, iz szczególne cechy Unii i jej prawa zostana zachowane ${ }^{150}$.

Jeśli chodzi o procedurę wcześniejszego zaangażowania, to zdaniem Trybunału powinna ona zostać uksztattowana w taki sposób, by w kazdej sprawie zawistej przed ETPC Unia byta w petni i systematycznie informowana, tak by wtaściwa instytucja Unii byta $w$ stanie ocenić, czy Trybunat wypowiedziat się juz na temat kwestii będacej przedmiotem sporu w tej sprawie, a jeśli nie - to umożliwić uruchomienie tej procedury ${ }^{151}$. Ponadto Trybunał stwierdzil, że analizowany projekt wyklucza możliwość wystąpienia do Trybunału o wypowiedzenie się w kwestii wykładni prawa pochodnego Unii Europejskiej $\mathrm{w}$ drodze procedury wcześniejszego zaangażowania ${ }^{152}$. Ograniczenie zakresu stosowania procedury wcześniejszego zaangażowania w przypadku prawa pochodnego wytacznie do kwestii ważności narusza kompetencje Unii i uprawnienia Trybunatu, gdyż nie pozwala mu dokonywać ostatecznej wyktadni prawa pochodnego w świetle praw zagwarantowanych $w E K P C^{153}$.

Po szóste, Trybunał skonstatował, że analizowany projekt nie uwzględnia szczególnych cech prawa Unii Europejskiej wodniesieniu do kontroli sądowej aktów, dziatań lub zaniechań Unii we wspólnej polityce zagranicznej i bezpieczeństwa, gdyż powierza uprawnienia $\mathrm{w}$ tym zakresie wyłącznie organowi zewnętrznemu w stosunku do Unii, jakim jest ETPCz $z^{154}$. Projekt nadaje bowiem ETPCz prawo do orzekania o zgodności z EKPCz niektórych aktów, dziatań lub zaniechań majacych miejsce w ramach WPZiB, zwtaszcza tych, wodniesieniu do których Trybunat nie jest wtaściwy, by skontrolować ich legalność w świetle praw podstawowych ${ }^{155}$. Zdaniem Trybunału taka sytuacja oznaczataby powierzenie kontroli sadowej wspomnianych aktów, dziatań lub zaniechań Unii wytacznie organowi zewnętrznemu w stosunku do Unii, nawet jeśli

147 Motyw 224 Opinii 2/13 Trybunału.

148 Motyw 225 Opinii 2/13 Trybunału.

149 Motyw 227 Opinii 2/13 Trybunału.

150 Motyw 235 Opinii 2/13 Trybunału.

151 Motyw 241 Opinii 2/13 Trybunału.

152 Motyw 243 Opinii 2/13 Trybunału.

153 Motyw 247-248 Opinii 2/13 Trybunału.

154 Motyw 257 Opinii 2/13 Trybunału.

155 Motyw 254 Opinii 2/13 Trybunału. 
kontrola ta miataby być tylko ograniczona do zgodności z prawami zagwarantowanymi $w E K P C^{156}$.

Opinia Trybunału Sprawiedliwości Unii Europejskiej z 18 grudnia 2014 r., w której stwierdził on niezgodność projektu umowy akcesyjnej z art. 6 ust. 2 TUE oraz protokołem nr 8 w sprawie przystąpienia Unii Europejskiej do EKPCz, oznacza, że Unia nie będzie mogła związać się tą umową, chyba że wynegocjowana zostanie zmiana jej treści lub zmiana traktatów.

\section{WSPÓLNA POLITYKA BEZPIECZEŃSTWA I OBRONY UNII EUROPEJSKIEJ}

\section{IV.1. Klauzula solidarności}

W ramach procesu implementacji przepisów art. 222 ust. 3 TFUE wysoka przedstawiciel Unii i Komisja Europejska złożyły 21 grudnia 2012 r. wspólny wniosek określający procedury i zasady stosowania klauzuli solidarności ${ }^{157}$. Jeszcze w tym samym dniu wniosek ten został przekazany Radzie Unii Europejskiej oraz poinformowany o nim został Parlament Europejski. Już miesiąc wcześniej, 22 listopada 2012 r., Parlament Europejski uchwalił rezolucję w sprawie klauzul: solidarności i sojuszniczej. Jeśli chodzi o pierwszą klauzulę, to Parlament wezwał wysoką przedstawiciel Unii i Komisję Europejską, aby przed końcem 2012 r. przedstawity one zgodnie z przepisami art. 222 ust. 3 TFUE wspólny wniosek dotyczący decyzji Rady Unii Europejskiej określającej warunki stosowania klauzuli solidarności, precyzując w szczególności rolę i uprawnienia rożnych podmiotów. W związku z tym zaapelował on także do Komitetu Politycznego i Bezpieczeństwa oraz Stałego Komitetu Współpracy Operacyjnej w Zakresie Bezpieczeństwa Wewnętrznego o przedstawienie wspólnej opinii $w$ sprawie zastosowania klauzuli solidarności z uwzględnieniem politycznego i operacyjnego wymiaru obu klauzul (solidarności i sojuszniczej), w tym także relacji pomiędzy Unią Europejską a NATO ${ }^{158}$.

24 czerwca 2014 r. Rada Unii Europejskiej, stanowiąc większością kwalifikowaną, przyjęła decyzję ustanawiającą zasady i procedury dotyczące stosowania przez Unię Europejską klauzuli solidarności ${ }^{159}$. Decyzja ta stanowi, że w razie ataku terrorystycznego, klęski żywiołowej lub katastrofy spowodowanej przez człowieka poszkodowane państwo członkowskie Unii może powotaćsię na klauzulę solidarności, o ile - po wyczerpaniu możliwości, jakie oferują istniejące środki i narzędzia na poziomie krajowym

156 Motyw 255 Opinii 2/13 Trybunału.

157 Art. 222 ust. 1-4 TFUE.

158 Rezolucja Parlamentu Europejskiego z dnia 22 listopada 2012 r. wsprawie klauzul wzajemnej obrony isolidarności UE: wymiaru politycznego i operacyjnego (2012/2223/(INI)), P7_TA-PROV(2012)0456, s. 5.

159 Decyzja Rady z dnia 24 czerwca 2014 r. w sprawie uzgodnień dotyczacych zastosowania przez Unię klauzuli solidarności, Dz. U. UE 2014, L 192, s. 53-58. 
i unijnym - uzna, że dana sytuacja kryzysowa zdecydowanie przekroczyta dostepna dla tego państwa zdolność reagowania. W ślad za tym władze polityczne takiego państwa winny się zwrócić do prezydencji i Komisji Europejskiej ze specjalnym wnioskiem, powołując się na klauzulę solidarności. Rada Unii Europejskiej winna koordynować działania oraz zapewniać strategiczne kierownictwo w sposobie reagowania Unii na zaistniałą sytuację kryzysową, wykorzystując do tego celu zintegrowany mechanizm reagowania kryzysowego na szczeblu politycznym, ustanowiony na mocy decyzji Rady Unii Europejskiej z 23 czerwca 2013 r., a także uwzględniając kompetencje wysokiego przedstawiciela Unii oraz Komisji Europejskiej (art. 4 ust. 1-2 oraz art. 5 ust. 1 decyzji $)^{160}$.

Decyzja Rady Unii Europejskiej z 24 czerwca 2014 r. podlega wszakże trzem istotnym ograniczeniom: po pierwsze, nie ma ona wpływu na kwestie obronne, choć przepisy art. 222 ust. 3 TFUE dopuszczają taką możliwość (art. 2 ust. 2 decyzji) ${ }^{161}$; po drugie, nie narusza art. 42 ust. 7 TUE określającego klauzulę sojuszniczą, co oznacza, że w przypadku kryzysu wymagającego podjęcia działań w ramach wspólnej polityki zagranicznej i bezpieczeństwa lub wspólnej polityki bezpieczeństwa i obrony konieczne będzie przyjęcie przez Radę innej decyzji, zgodnie z odpowiednimi postanowieniami traktatów (akapity 13 i 14 preambuły do decyzji) ${ }^{162}$; po trzecie, decyzja ta nie dotyczy zastosowania przez państwa członkowskie klauzuli solidarności na mocy art. 222 ust. 2 TFUE. Zgodnie z deklaracją nr 37 odnoszącą się do art. 222 TFUE państwo członkowskie ma mieć zagwarantowane prawo wyboru najbardziej odpowiednich środków w celu wypełnienia przez nie obowiązku solidarności w stosunku do innego państwa członkowskiego (akapit 1 preambuły do decyzji) ${ }^{163}$.

\section{IV.2. Klauzula sojusznicza oraz przepisy art. 42 ust. 3 TUE}

Odrębnym problemem są przepisy dotyczące klauzuli sojuszniczej (art. 42 ust. 7 TUE) oraz zdolności cywilnych i wojskowych państw członkowskich, oddawanych przez te państwa do dyspozycji Unii Europejskiej (art. 42 ust. 3 TUE). W obydwu przypadkach traktat nie precyzuje bowiem procedur i zasad zastosowania tychże przepisów. Art. 42 ust. 7 TUE stanowi, że państwa członkowskie maja [...] obowiąek udzielenia pomocy i wsparcia przy zastosowaniu wszelkich dostępnych im środków, zgodnie z artykutem 51 Karty Narodów Zjednoczonych"164. Ponieważ art. 42 ust. 7 TUE nie zawiera przepisu upoważniającego Radę Europejską lub Radę Unii Europejskiej do zastosowania klauzuli sojuszniczej, a z drugiej strony art. 13 ust. 2 TUE precyzuje, że każda instytucja Unii Europejskiej działa $w$ granicach uprawnień

160 Tamże, s. 56.

161 Tami̇e, s. 55.

162 Tamże, s. 54.

163 Tamże, s. 53; Deklaracja odnosząca się do artykutu 222 Traktatu of funkcjonowaniu Unii Europejskiej, [w:] Traktat z Lizbony, s. 349.

164 Art. 42 ust. 7 TUE. 
przyznanych jej na mocy Traktatów, zgodnie z procedurami, na warunkach $i$ w celach $w$ nich określonych, oznacza to, że wyłącznie państwa członkowskie mogą decydować o udzieleniu sobie wzajemnej pomocy i to - w tym przypadku - jednomyślnie. Podobnie rzecz się ma z przepisami art. 42 ust. 3 TUE, który stanowi, że państwa cztonkowskie [...] oddaja do dyspozycji Unii swoje zdolności cywilne i wojskowe, aby przyczynić się do osiagnięcia celów określonych przez Radę. Dotyczy to także państw wspólnie powołujących siły wielonarodowe, które to siły również mogą być przekazane Unii Europejskiej. Także i w tym przypadku decyzje są zastrzeżone wyłącznie dla państw członkowskich.

Warto zwrócić uwagę, że Parlament Europejski w przywołanej wyżej rezolucji z 22 listopada 2012 r. wskazał na jeszcze inną drogę prawną, umożliwiającą implementację przepisów art. 42 ust. 7 TUE. Jego zdaniem, w celu zastosowania tej klauzuli należałoby skorzystać z postanowień art. 32 TUE, przewidującego konsultacje państw członkowskich w duchu solidarności na forum Rady Europejskiej i Rady Unii Europejskiej w sprawie wszelkich kwestii polityki zagranicznej i bezpieczeństwa, stanowiących przedmiot ogólnego zainteresowania, ale bez uszczerbku dla przystugującego każdemu państwu cztonkowskiemu prawa do równolegtego organizowania wtasnej obrony. Parlament zwrócił się nawet w tej sprawie do wysokiej przedstawiciel Unii, aby zaproponowata [ona] praktyczne ustalenia $i$ wytyczne w celu zapewnienia efektywnych dziatań w odpowiedzi na powotanie sięprzez którekolwiek z pañstw cztonkowskich na klauzulę o wzajemnej obronie [klauzulę sojuszniczą - J.J.W.], a także analizę roli, jaka odegrać powinny instytucje UE w sytuacji powotania się na tę klauzule. W opinii Parlamentu „zobowiązanie do zapewnienia sobie pomocy i wsparcia” byłoby również „wyrazem politycznej solidarności między państwami członkowskimi" ${ }^{65}$. Jednak propozycje Parlamentu Europejskiego nie znalazły większego odzewu po stronie rządów państw członkowskich.

\section{PROTOKÓŁ IRLANDZKI}

Protokół irlandzki ma swoją genezę w odrzuceniu przez społeczeństwo tego państwa 12 czerwca 2008 r. traktatu lizbońskiego. Już pod koniec lipca 2008 r. rząd irlandzki podjął decyzję o powtórzeniu referendum jesienią 2009 r. pod warunkiem zachowania własnego komisarza w Komisji Europejskiej, potwierdzenia polityki neutralności Irlandii oraz nieuczestniczenia tego państwa w planowanej wspólnej polityce obronnej Unii Europejskiej, a także utrzymania niezależności w polityce podatkowej i wzmocnienia zakazu aborcji ${ }^{166}$.

Podczas posiedzenia Rady Europejskiej w dniach 11-12 grudnia 2008 r. w Brukseli irlandzki premier Brian Cowen oficjalnie potwierdził decyzję o przeprowadzeniu drugiego referendum nad traktatem lizbońskim. Natomiast Rada Europejska określi-

165 Rezolucja Parlamentu Europejskiego z dnia 22 listopada 2012 r..., s. 6.

166 Szerzej na ten temat por.: J.J. Węc, Traktat Lizboński..., s. 286-287. 
ła sposób postępowania, który miał pozwolić na jego wejście w życie przed końcem 2009 r. W konkluzjach przyjętych wówczas przez Radę Europejską postanowiono, że Irlandii przyznane zostaną gwarancje prawne w trzech następujących dziedzinach: polityce podatkowej, polityce bezpieczeństwa i obrony oraz prawie do życia, edukacji i rodziny. Ich spełnienie zostało uzależnione od tego, czy rząd irlandzki podejmie starania o ratyfikację traktatu lizbońskiego jeszcze przed upływem bieżącej kadencji Komisji Europejskiej ${ }^{167}$.

W czasie posiedzenia Rady Europejskiej w dniach 18-19 czerwca 2009 r. w Brukseli uzgodniono pakiet negocjacyjny, na który złożyły się: po pierwsze, decyzja w sprawie obaw narodu irlandzkiego co do traktatu z Lizbony, przyjęta przez szefów państw lub rządów (załącznik I do konkluzji); po drugie, uroczysta deklaracja o prawach pracowniczych, polityce społecznej i innych kwestiach, uchwalona przez Radę Europejską (załącznik II do konkluzji); po trzecie, jednostronna deklaracja Irlandii w sprawie polityki bezpieczeństwa i obrony, przyjęta do wiadomości przez Radę Europejską, która winna być następnie załączona do irlandzkiego instrumentu ratyfikującego traktat lizboński (załącznik III do konkluzji) ${ }^{168}$.

Decyzja szefów państw lub rządów z 19 czerwca 2009 r. w sprawie obaw narodu irlandzkiego co do traktatu z Lizbony przyznawała Irlandii gwarancje prawne w trzech wspomnianych wyżej dziedzinach: prawie do życia, edukacji i rodziny, polityce podatkowej, a także polityce bezpieczeństwa i obrony. Stwierdzono w niej po pierwsze, że żadne z postanowień traktatu lizbońskiego nadających status prawny KPP, ani żadne z postanowień tego traktatu dotyczące przestrzeni wolności, bezpieczeństwa i sprawiedliwości, $w$ żaden sposób nie narusza zakresu ani możliwości zastosowania przepisów konstytucji Irlandii, chroniących prawo do życia, rodzinę i prawa edukacyjne. Po drugie, podniesiono, że przepisy traktatu lizbońskiego nie zmieniają - w odniesieniu do wszystkich państw członkowskich - zakresu kompetencji Unii Europejskiej w dziedzinie opodatkowania ani sposobu wykonywania przez nia tych kompetencji. Po trzecie, wskazano, że wspólna polityka bezpieczeństwa i obrony Unii Europejskiej nie uchybia ani polityce bezpieczeństwa i obrony, ani zobowiązaniom jakiegokolwiek państwa członkowskiego, w tym Irlandii. Traktat lizboński nie wpływa, ani nie uchybia tradycyjnej irlandzkiej polityce neutralności wojskowej ${ }^{169}$. Ponadto szefowie państw lub rządów oświadczyli, że ich decyzja jest prawnie wiążąca i stanie się skuteczna w momencie wejścia w życie traktatu lizbońskiego, zaś przy okazji zawarcia następnego traktatu akcesyjnego jej postanowienia zostaną ujęte w specjalnym protokole, który zostanie załączony do TUE i TFUE ${ }^{170}$.

Rada Europejska w uchwalonej przez siebie uroczystej deklaracji w sprawie praw pracowniczych, polityki społecznej i innych kwestii zapewniła natomiast m.in., że trak-

167 Posiedzenie Rady Europejskiej w Brukseli, 11 -12 grudnia 2008 r...., s. 1-3, 12 (załącznik I do konkluzji). Szerzej na ten temat por.: J.J. Węc, Traktat Lizboński..., s. 287-288.

168 Posiedzenie Rady Europejskiej w Brukseli, 18-19 czerwca 2009 r...., s. 2-4.

169 Tamże, s. 17-19 (załącznik I do konkluzji).

170 Tamże, s. 3 (konkluzje). 
tat lizboński, wprowadzając zmiany do TUE i TWE, ma na celu zwalczanie wykluczenia społecznego i dyskryminacji oraz wspieranie sprawiedliwości i ochrony socjalnej, równości kobiet i mężczyzn, solidarności między pokoleniami i ochrony praw dziec$\mathrm{ka}^{171}$.Z kolei rząd irlandzki w jednostronnej deklaracji jeszcze raz oświadczył, że uczestnictwo Irlandii we wspólnej polityce zagranicznej i bezpieczeństwa Unii Europejskiej nie uchybia jej tradycyjnej polityce neutralności wojskowej, a Irlandia nie podlega żadnemu wzajemnemu zobowiązaniu o charakterze obronnym. Konstytucja Irlandii wymagałaby w tym celu przeprowadzenia referendum. Rząd stwierdził również, że nic nie zobowiązuje Irlandii do uczestnictwa w stałej współpracy strukturalnej przewidzianej w traktacie lizbońskim, w pracach Europejskiej Agencji Obrony, ani w poszczególnych projektach lub programach realizowanych pod jej auspicjami. Wszelkie decyzje dotyczące takiego uczestnictwa będą musiały zostać zatwierdzone przez parlament irlandzki ${ }^{172}$.

W ślad za wspomnianą wyżej decyzją szefów państw lub rządów w połowie $2011 \mathrm{r}$. rozpoczęto prace nad protokołem irlandzkim w oparciu o zwykłą procedurę rewizji traktatów (art. 48 ust. 2-5 TUE). 20 lipca 2011 r. rząd Irlandii skierował do polskiej prezydencji wniosek dotyczący dodania do TUE i TFUE projektu protokołu odnoszącego się do obaw narodu irlandzkiego co do traktatu lizbońskiego. 12 października 2011 r. Rada Unii Europejskiej przedłożyła Radzie Europejskiej wniosek rządu irlandzkiego, a także notyfikowała go parlamentom narodowym. 23 października tegoż roku Rada Europejska podjęła konsultacje z Parlamentem Europejskim i Komisją Europejską, a także postanowiła zwrócić się do Parlamentu o wyrażenie zgody na niezwoływanie konwentu. Gdy Parlament i Komisja - odpowiednio: 18 kwietnia i 4 maja 2012 r. opowiedziały się za rozpatrzeniem proponowanych zmian, a Parlament zgodził się nadto na niezwoływanie konwentu, Rada Europejska 11 maja 2012 r. przyjęła decyzję o zwołaniu konferencji międzyrządowej bez udziału konwentu oraz określiła jej mandat, który był tożsamy z treścią protokołu w sprawie obaw narodu irlandzkiego co do Traktatu z Lizbony ${ }^{173}$.

Podobnie jak w przypadku wspomnianej wyżej zmiany protokołu nr $36 \mathrm{w}$ sprawie postanowień przejściowych - konferencja międzyrządowa obradowała tylko jeden dzień, a mianowicie 16 maja 2012 r. na szczeblu COREPER II, kiedy to otwarto procedurę podpisywania protokołu, określając zarazem termin jej zakończenia do 30 czerwca tegoż roku ${ }^{174}$. Polska uczyniła to 30 maja 2012 r., zaś wszystkie państwa członkowskie do 13 czerwca 2012 r. ${ }^{175}$ Protokół wymagał ratyfikacji przez wszystkie państwa członkowskie zgodnie z ich wymogami konstytucyjnymi. Miał on wejść w życie $30 \mathrm{czerw}-$

171 Tamże, s. 20-21. Szerzej na ten temat por.: J.J. Węc, Traktat Lizboński..., s. 288-290.

172 Posiedzenie Rady Europejskiej w Brukseli, 18-19 czerwca 2009 r...., s. 22-23. Szerzej na ten temat por.: J.J. Węc, Traktat Lizboński..., s. 290-291.

173 Przebieg prac nad protokołem irlandzkim por.: Sejm Rzeczypospolitej Polskiej, VII kadencja. Prezes Rady Ministrów. RM 10-138-12. Druk nr 1047, Warszawa, 11 I 2013, s. 5.

174 Tamże.

175 Protokót w sprawie obaw narodu irlandzkiego co do Traktatu z Lizbony, Dz. U. UE 2013, L 60, s. 131-133 . 
ca 2013 r., jeżeli do tego czasu złożone zostałyby wszystkie dokumenty ratyfikacyjne lub pierwszego dnia miesiąca następującego po złożeniu dokumentu ratyfikacyjnego przez państwo członkowskie, które jako ostatnie dopełni tej formalności (art. 4 protokołu) ${ }^{176}$. Polska ratyfikowała protokół 22 lipca 2013 r. Po zatwierdzeniu go przez pozostałe państwa protokół wszedł w życie 1 grudnia 2014 r. ${ }^{177}$

W protokole irlandzkim znalazły się gwarancje zapewniające wyłącznie Irlandii, że żadne z postanowień traktatu lizbońskiego nadających moc prawną KPP Unii Europejskiej ani żaden z przepisów tegoż traktatu, dotyczących obszaru wolności, bezpieczeństwa i sprawiedliwości nie narusza zakresu ani możliwości zastosowania postanowień konstytucji Irlandii, odnoszących się do ochrony prawa do życia, ochrony rodziny oraz ochrony praw w zakresie edukacji (art. 1 protokołu) ${ }^{178}$. Stanowit on

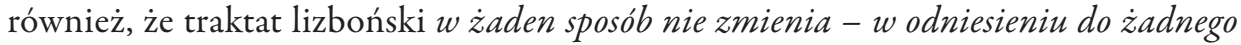
Państwa Cztonkowskiego - zakresu kompetencji Unii Europejskiej w dziedzinie opodatkowania ani sposobu wykonywania przez nia tych kompetencji (art. 2 protokołu) ${ }^{179}$. Precyzował także, że przepisy traktatu lizbońskiego dotyczące wspólnej polityki bezpieczeństwa i obrony w żaden sposób nie naruszają polityki bezpieczeństwa i obrony Irlandii, ani też jej zobowiązań w tej dziedzinie. Nie wpływają one na tradycyjna irlandzka politykę neutralności wojskowej ani jej nie narusza. Traktat ten przewiduje wszakże obowiązek udzielania wspólnej pomocy w duchu solidarności, jeżeli jedno z państw członkowskich stanie się ofiarą agresji na swoim terytorium w rozumieniu odpowiednio art. 42 ust. 7 TUE oraz art. 222 TFUE. Jednak od państw członkowskich, - w tym Irlandii, dziatającej $w$ duchu solidarności i bez uszczerbku dla jej tradycyjnejpolityki neutralności wojskowej - zależéc będzie, jak określac charakter pomocy lub wsparcia dla Państwa Cztonkowskiego, będacego przedmiotem ataku terrorystycznego lub ofiara agresji zbrojnej na swoim terytorium. Zgodnie z postanowieniami traktatu lizbońskiego i krajowymi wymogami prawnymi każde państwo członkowskie podejmie również samodzielnie decyzję, czy uczestniczyć w stałej współpracy strukturalnej lub w pracach Europejskiej Agencji Obrony. Traktat nie przewiduje utworzenia armii europejskiej ani poboru do jakiejkolwiek formacji wojskowej. Nie wptywa on na prawo Irlandii ani żadnego innego Państwa Cztonkowskiego do określenia charakteru i zakresu swoich wydatków na obronę i bezpieczeństwo oraz do określenia charakteru swoich zdolności obronnych. Irlandia lub każde inne Państwo Cztonkowskie podejma decyzjezgodnie z krajowymi wymogami prawnymi - czy uczestniczyć w określonej operacji wojskowej (art. 3 protokołu) $)^{180}$.

176 Tamże, s. 132-133.

177 Oświadczenie rządowe $z$ dnia 9 lutego 2015 r. w sprawie mocy obowiązujacej protokotu $w$ sprawie obaw narodu irlandzkiego co do Traktatu z Lizbony, sporzadzonego w Brukseli dnia 13 czerwca 2012 r., Dz. U. 2015, poz. 304.

178 Protokót w sprawie obaw narodu irlandzkiego co do Traktatu z Lizbony, s. 132.

179 Tamże.

180 Tamże. 


\section{UWAGI KOŃCOWE}

Proces implementacji przepisów traktatu lizbońskiego rozpoczął się już w dniu jego wejścia w życia i trwa nadal. W dotychczasowym jego przebiegu możemy wyróżnić zarówno akty prawa pochodnego i prawa pierwotnego, które weszły już w życie, jak i akty, które nie weszły jeszcze w życie lub znajdują się dopiero w toku procesu legislacyjnego. Wśród aktów prawa pochodnego i pierwotnego, które weszły już w życie, znajdują się przede wszystkim akty dotyczące systemu instytucjonalnego Unii, w szczególności składu Parlamentu Europejskiego na okres VIII kadencji w latach 2014-2019, liczby członków kolegium Komisji Europejskiej, zwiększenia liczby rzeczników generalnych Trybunału Sprawiedliwości Unii Europejskiej oraz zasad działania komitetu opiniodawczego w czasie procedury powoływania Trybunału Sprawiedliwości i Sądu, wyboru przewodniczącego Rady Europejskiej oraz wysokiego przedstawiciela Unii ds. zagranicznych i polityki bezpieczeństwa, uzupełnienia wykazu formacji Rady Unii Europejskiej, organizacji i zasad funkcjonowania Europejskiej Służby Działań Zewnętrznych, ustanowienia i zdefiniowania zadań Stałego Komitetu Współpracy Operacyjnej w Zakresie Bezpieczeństwa Wewnętrznego, a także nadania statusu traktatowego i określenia zasad funkcjonowania Europejskiej Agencji Obrony. Ponadto do kategorii aktów prawa pochodnego, które weszły już w życie, należą przepisy dotyczące aktów delegowanych, aktów wykonawczych, inicjatywy obywatelskiej oraz klauzuli solidarności. Spośród aktów prawa pierwotnego, które również weszły już w życie, wymienić należy: protokół z 23 czerwca 2010 r. dotyczący rewizji protokołu nr $36 \mathrm{w}$ sprawie postanowień przejściowych oraz protokół z 13 czerwca 2012 r. odnoszący się do obaw narodu irlandzkiego co do Traktatu z Lizbony.

Spośród aktów prawa pierwotnego i wtórnego, które nie weszły jeszcze w życie lub nie zostały w ogóle uchwalone (podpisane), wymienić należy przede wszystkim uzgodniony już pomiędzy Komisją Europejską a Komitetem Sterującym Rady Europy ds. Praw Człowieka projekt umowy o akcesji Unii Europejskiej do EKPCz, którego zgodność z traktatami unijnymi 18 grudnia 2014 r. zakwestionował Trybunał Sprawiedliwości Unii Europejskiej, tzw. protokół czeski, którego celem miało być przystąpienie Republiki Czeskiej do protokołu brytyjskiego w sprawie Karty Praw Podstawowych, ale z którego to przystąpienia zrezygnował sam czeski rząd ${ }^{181}$, a także znajdujący się w toku procesu legislacyjnego projekt rozporządzenia Rady Unii Europejskiej z 17 lipca 2013 r. w sprawie ustanowienia Prokuratury Europejskiej.

181 Dnia 20 lutego 2014 r. premier Czech Bohuslav Sobotka podczas wizyty w Brukseli przedstawił nowe założenia polityki europejskiej tamtejszego rządu, wśród których znalazły się m.in. deklaracja o przystąpieniu Republiki Czeskiej do paktu fiskalnego oraz rezygnacja ze starań o ratyfikację protokołu czeskiego. Por.: J. Groszkowski, Ostrożne zmiany w czeskiej polityce europejskiej, Ośrodek Studiów Wschodnich. Analizy, 26 II 2014, s. 1-2. Na temat innych przyczyn rezygnacji rządu czeskiego z protokołu por.: J. Barcz, Unia Europejska w dobie reform. Podstawy prawne. Wybór dokumentów, Warszawa 2013, s. 13. 


\section{BIBLIOGRAFIA}

\section{I. Źródła}

Akt dotyczący wyborów cztonków Parlamentu Europejskiego w powszechnych wyborach bezpośrednich z 20 września 1976 r., [online] http://oide.sejm.gov.pl/oide/images/files/dokumenty/ wybory_pe.pdf.

Council Decision of 13 July 1987 laying down the procedures for the exercise of implementing powers conferred on the Commission (87/373/EEC), O.J. EC 1987, L 197.

Council Decision of 28 June 1999 laying down the procedures for the exercise of implementing powers conferred on the Commission (1999/468/EC), O.J. EC 1999, L 184.

Council of Europe, $8^{\text {th }}$ Working of the CDDH Informal Working Group on the Accession of the European Union to the European Convention on Human Rights (CDDH-UE) with the European Commission, CDDH-UE(2011)11, Strasbourg, 15 VI 2011.

Council of Europe, Fifth Negotiation Meeting between the CDDH ad hoc Negotiation Group and the European Commission on the Accession of the European Union to the European Convention on Human Rights. Final Report to the CDDH, 47+1(2013)008, Strasbourg, 5 IV 2013.

Council of the European Union, Common Understanding on delegated acts, 8640/11, Brussels, 4 IV 2011.

Council of the European Union, Terminology to be used in Council and COREPER agendas for legislative items under the Ordinary Legislative Procedure (OLP), 5084/12, Brussels, 13 I 2012.

Decyzja Parlamentu Europejskiego z dnia 6 maja 2010 r. w sprawie wniosku Rady Europejskiej dotyczącego niezwotywania konwentu w celu zmiany traktatów w zakresie środków przejściowych dotyczacych sktadu Parlamentu Europejskiego (17196/2009-C7-0002/2010-2009/0814(NL E)), Dz. U. UE 2010, C 81.

Decyzja Rady (do Spraw Ogólnych) z dnia 1 grudnia 2009 r. ustanawiająca wykaz sktadów Rady uzupetniajacy sktady, o których mowa $w$ art. 16 ust. 6 akapity drugi i trzeci Traktatu o Unii Europejskiej, Dz. U. UE 2009, L 315.

Decyzja Rady Europejskiej podjęta za zgoda przewodniczącego Komisji z dnia 1 grudnia 2009 r. w sprawie mianowania wysokiego przedstawiciela Unii ds. zagranicznych i polityki bezpieczeństwa, Dz. U. UE 2009, L 315.

Decyzja Rady Europejskiej z dnia 1 grudnia 2009 r. w sprawie wyboru przewodniczacego Rady Europejskiej, Dz. U. UE 2009, L 315.

Decyzja Rady Europejskiej z dnia 16 września 2010 r. w sprawie zmiany wykazu sktadów Rady, Dz. U. UE 2010, L 263.

Decyzja Rady Europejskiej z dnia 22 maja 2013 r. w sprawie liczby cztonków Komisji Europejskiej, Dz. U. UE 2013, L 165.

Decyzja Rady Europejskiej z dnia 28 czerwca 2013 r. ustanawiająca sktad Parlamentu Europejskiego, Dz. U. UE 2013, L 181.

Decyzja Rady z dnia 12 lipca 2011 r. określająca statut, siedzibę i zasady operacyjne Europejskiej Agencji Obrony oraz uchylajaca wspólne dziatanie 2004/551/WPZiB, Dz. U. UE 2011, L 183. 
Decyzja Rady z dnia 17 lipca 2006 r. zmieniająca decyzje 1999/468/WE ustanawiająca warunki wykonywania uprawnień wykonawczych przyznanych Komisji (2006/512/WE), Dz. U. UE 2006, L 200.

Decyzja Rady z dnia 24 czerwca 2014 r. w sprawie uzgodnień dotyczacych zastosowania przez Unię klauzuli solidarności, Dz. U. UE 2014, L 192.

Decyzja Rady z dnia 25 czerwca 2013 r. w sprawie zwiększenia liczby rzeczników generalnych Trybunatu Sprawiedliwości Unii Europejskiej, Dz. U. UE 2013, L 179.

Decyzja Rady z dnia 25 lutego 2010 r. w sprawie ustanowienia Statego Komitetu Wspótpracy Operacyjnej $w$ Zakresie Bezpieczeństwa Wewnętrznego, Dz. U. UE 2010, L 52.

Decyzja Rady z dnia 25 lutego 2010 r. w sprawie zasad dziatania komitetu, o którym mowa wart. 255 Traktatu ofunkcjonowaniu Unii Europejskiej, Dz. U. UE 2010, L 50.

Decyzja Rady z dnia 26 lipca 2010 r. określajaca organizację i zasady funkcjonowania Europejskiej Stużby Dziatań Zewnętrznych (2010/427/UE), Dz. U. UE 2010, L 201.

Informacja dla Sejmu i Senatu o udziale Rzeczypospolitej Polskiej w pracach Unii Europejskiej w okresie styczeń-czerwiec 2010 roku (podczas prezydencji hiszpańskiej), Warszawa 2010.

Informacja dla Sejmu i Senatu o udziale Rzeczypospolitej Polskiej w pracach Unii Europejskiej w okresie styczeń-czerwiec 2011 roku (podczas prezydencji wegierskiej), Warszawa 2011.

Informacja dla Sejmu i Senatu Rzeczypospolitej Polskiej o udziale Rzeczypospolitej Polskiej w pracach Unii Europejskiej w okresie lipiec-grudzień 2010 r. (podczas prezydencji belgijskiej), Warszawa 2011.

KM 2007, Sprostowanie do noty od prezydencji do konferencji międzyrządowej. Projekty deklaracji: Deklaracja nr 39a odnoszaca się do artykutu 222 Traktatu o funkcjonowaniu Unii Europejskiej w sprawie liczby rzeczników generalnych w Trybunale Sprawiedliwości Unii Europejskiej, CIG 3/1/07, REV 1, COR 2, Bruksela, 22 X 2007.

KM 2010, Protokót zmieniający Protokót w sprawie postanowień przejściowych, dotacczony do Traktatu o Unii Europejskiej, do Traktatu o funkcjonowaniu Unii Europejskiej i do Traktatu ustanawiajacego Europejską Wspólnotę Energii Atomowej, CIG 1/10, Bruksela, 11 VI 2010.

KM 2010, Wstępny porządek obrad konferencji międzyrządowej w dniu 23 czerwca $2010 \mathrm{r}$. w Brukseli, CIG 2/10, Bruksela, 22 VI 2010.

Komisja Europejska, Komunikat Komisji do Parlamentu Europejskiego i Rady. Wprowadzenie $w$ życie art. 290 Traktatu ofunkcjonowaniu Unii Europejskiej, COM(2009) 673 wersja ostateczna, Bruksela, 9 XII 2009.

Komisja Europejska, Wniosek. Rozporządzenie Parlamentu Europejskiego i Rady ustanawiajace przepisy i zasady ogólne dotyczące trybu kontroli przez państwa cztonkowskie wykonywania uprawnień wykonawczych przez Komisje, COM(2010) 83 wersja ostateczna, Bruksela, 9 III 2010.

Komisja Europejska, Wniosek. Rozporządzenie Parlamentu Europejskiego i Rady w sprawie inicjatywy obywatelskiej, $\operatorname{COM(2010)~} 119$ wersja ostateczna, Bruksela, 31 III 2010.

Komisja Europejska, Wniosek. Rozporządzenie Rady w sprawie ustanowienia Prokuratury Europejskiej, $\operatorname{COM}(2013) 534$ wersja ostateczna, Bruksela, 17 VII 2013.

Oświadczenie rządowe z dnia 9 lutego 2015 r. w sprawie mocy obowiazującej protokotu w sprawie obaw narodu irlandzkiego co do Traktatu z Lizbony, sporzadzonego w Brukseli dnia 13 czerwca 2012 r., Dz. U. 2015, poz. 304. 
Posiedzenie Rady do Spraw Ogólnych w dniu 14 czerwca 2010 r. Komunikat prasowy, 11021/10, Bruksela, 14 VI 2010.

Posiedzenie Rady ds. Wymiaru Sprawiedliwości i Spraw Wewnętrznych w dniach 13-14 grudnia 2011 r. Komunikat prasowy, 18498/11, Bruksela, 13-14 XII 2011.

Posiedzenie Rady Europejskiej w Brukseli, 10-11 grudnia 2009 r. Konkluzje prezydencji, EUCO 6/09, Bruksela, 11 XII 2009.

Posiedzenie Rady Europejskiej w Brukseli, $11-12$ grudnia 2008 r. Konkluzje prezydencji, 17271/1/08, REV 1, Bruksela, 13 II 2009.

Posiedzenie Rady Europejskiej w Brukseli, 14 grudnia 2007 r. Konkluzje prezydencji, 16616/1/07, REV 1, Bruksela, 14 II 2008.

Posiedzenie Rady Europejskiej w Brukseli, 17 czerwca 2010 r. Konkluzje prezydencji, EUCO 13/10, Bruksela, 17 VI 2010.

Posiedzenie Rady Europejskiej w Brukseli, 18-19 czerwca 2009 r. Konkluzje prezydencji, 11225/ 2/09, REV 2, Bruksela, 10 VII 2009.

Prezydencja do Rady i Rady Europejskiej. Sprawozdanie z postęu prac przygotowawczych. Wprowadzenie w żcie traktatu z Lizbony, 17033/1/09 REV 1, Bruksela, 4 XII 2009.

Procedura 2013/0255/APP COM (2013) 534: Wniosek rozporzadzenie Rady w sprawie ustanowienia Prokuratury Europejskiej, Eur-Lex. Baza aktów prawnych Unii Europejskiej, [online] http://eur-lex.europa.eu/legal-content/ PL/HIS.

Protokót w sprawie obaw narodu irlandzkiego co do Traktatu z Lizbony, Dz. U. UE 2013, L 60.

Protokót zmieniajacy protokót w sprawie postanowień przejściowych, dotączony do traktatu o Unii Europejskiej, do traktatu o funkcjonowaniu Unii Europejskiej i do traktatu ustanawiajacego Europejska Wspólnotę Energii Atomowej, Dz. U. UE 2010, C 263.

Rada Unii Europejskiej, Nota prezydencji do COREPER II/Rady ds. Wymiaru Sprawiedliwości i Spraw Wewnętrznych. Przystapienie Unii do europejskiej Konwencji o ochronie praw cztowieka i podstawowych wolności, 18117/11, Bruksela, 6 XII 2011.

Rada Unii Europejskiej, Nota Sekretariatu Generalnego do COREPER II/Rady ds. Wymiaru Sprawiedliwości i Spraw Wewnętrznych. Projekt konkluzji Rady w sprawie roli Rady Unii Europejskiej w zapewnianiu skutecznego wprowadzania w życie Karty praw podstawowych Unii Europejskiej, 6387/11, Bruksela, 11 II 2011.

Rezolucja Parlamentu Europejskiego z 7 maja 2009 r. wzywajaca Komisje do sporządzenia wniosku w sprawie rozporzadzenia Parlamentu Europejskiego i Rady w sprawie realizacji inicjatywy obywatelskiej. Zatączik I, (2008/2169(INI)), P6_TA (2009)0389.

Rezolucja Parlamentu Europejskiego z dnia 11 października 2007 r. w sprawie sktadu Parlamentu Europejskiego (2007/2169(INI)), P6_TA(2007)0429.

Rezolucja Parlamentu Europejskiego z dnia 12 marca 2014 r. w sprawie wniosku dotyczacego rozporzadzenia Rady w sprawie ustanowienia Prokuratury Europejskiej, P7_TA-PROV (2014)0234.

Rezolucja Parlamentu Europejskiego z dnia 22 listopada 2012 r. w sprawie klauzul wzajemnej obrony i solidarności UE: wymiaru politycznego i operacyjnego (2012/2223/(INI)), P7_TA-PROV(2012)0456.

Rezolucja Parlamentu Europejskiego z dnia 6 maja 2010 r. dotyczaca projektu protokotu zmieniającego protokót nr 36 w sprawie przepisów przejściowych w odniesieniu do sktadu Par- 
lamentu Europejskiego do końca kadencji 2009-2014: opinia Parlamentu Europejskiego (art. 48 ust. 3 traktatu UE) (17196/2009 - C7-0001/2010 - 2009/0813(NLE)), P7_ $\mathrm{TA}(2010) 0148$.

Rozporządzenie delegowane Komisji (UE) nr 268/2012 z dnia 25 stycznia 2012 r. zmieniajace zatacznik I do rozporzadzenia Parlamentu Europejskiego i Rady (UE) nr 211/2011 w sprawie inicjatywy obywatelskiej, Dz. U. UE 2012, L 89.

Rozporzadzenie Parlamentu Europejskiego i Rady (UE) NR 182/2011 z dnia 16 lutego 2011 r. ustanawiajace przepisy $i$ zasady ogólne dotyczace trybu kontroli przez państwa cztonkowskie wykonywania uprawnień wykonawczych przez Komisje, Dz. U. UE 2011, L 55.

Rozporządzenie Parlamentu Europejskiego i Rady (UE) Nr 211/2011 z dnia 16 lutego 2011 r. w sprawie inicjatywy obywatelskiej, Dz. U. UE 2011, L 65.

Sejm Rzeczypospolitej Polskiej, VII kadencja. Prezes Rady Ministrów. RM 10-138-12. Druk nr 1047, Warszawa, 11 I 2013.

Sekretariat Generalny Rady Unii Europejskiej, Nota informacyjna. Wptyw traktatu lizbońskiego na Radę ds. Wymiaru Sprawiedliwości i Spraw Wewnętrznych: szersza wspótdecyzja i nowe struktury, Bruksela 2009.

Traktat z Lizbony, zmieniajacy traktat o Unii Europejskiej i traktat ustanawiajacy Wspólnotę Europejska, podpisany w Lizbonie 13 grudnia 2007 r. (wersje skonsolidowane), Dz. U. UE 2008, C 115.

Trybunał Sprawiedliwości Unii Europejskiej, Opinia 2/13 Trybunatu (w petnym sktadzie), Luksemburg, 18 XII 2014.

Trybunał Sprawiedliwości Unii Europejskiej, Komunikat prasowy nr 139/13, Luksemburg, 23 X 2013.

\section{Monografie}

Barcz J., Traktat z Lizbony. Wybrane aspekty prawne dziatań implementacyjnych, Warszawa 2012, Monografie - LexiNexis Polska.

Barcz J., Unia Europejska w dobie reform. Podstawy prawne. Wybór dokumentów, Warszawa 2013.

Węc J.J., Spór o ksztatt ustrojowy Wspólnot Europejskich i Unii Europejskiej w latach 1950-2010. Między idea ponadnarodowości a wspótpraca międzyrządowa. Analiza politologiczna, Kraków 2012, Societas - Ksiegarnia Akademicka, 41.

Węc J.J., Traktat Lizboński. Polityczne aspekty reformy ustrojowej Unii Europejskiej w latach 2007-2009, Kraków 2011, Societas - Ksiegarnia Akademicka, 36.

\section{Artykuty}

Buchowska N., Starania Unii Europejskiej o przystąpienie do Konwencji o ochronie praw cztowieka i podstawowych wolności, „Przegląd Zachodni” 2014, nr 4.

Capik A.A., Gniewek A., Wprowadzenie do prawa europejskiej inicjatywy obywatelskiej, Luksemburg, 4 IV 2012, [online] http://www.euroinfo.krakow.pl/upload/Europejska\%20inicjatywa\%20obywatelska\%20-\%20B.\%20Capik\%20A.\%20Gniewek.pdf.

Europejska Służba Działań Zewnętrznych, [online] http://eeas.europa.eu/background/organisation/index_pl.htm. 
Formuszewicz R., Liszczyk D., Personel Europejskiej Stużby Dziatań Zewnętrznych do przegladu? Bilans i wnioski z dotychczasowej polityki kadrowej, Raport PISM, Warszawa 2012.

Gajda A., Przystapienie Unii Europejskiej do Europejskiej Konwencji o Ochronie Praw Cztowieka i Podstawowych Wolności, "Studia i Prace” (Kwartalnik Kolegium Ekonomiczno-Społecznego SGH) 2013, nr 1.

Groszkowski J., Ostrożne zmiany w czeskiej polityce europejskiej, Ośrodek Studiów Wschodnich. Analizy, 26 II 2014.

Herma C., Likwidacja „struktury filarowej” Unii - podmiotowość prawnomiędzynarodowa UE oraz reforma systemu aktów prawa pierwotnego i wtórnego, [w:] Traktat z Lizbony. Gtówne reformy ustrojowe Unii Europejskiej, red. nauk. J. Barcz, Warszawa 2008.

Lieb J., Kremer M., Der Aufbau des Europäischen Auswärtigen Dienstes. Stand und Perspektiven, „Integration” 2010, nr 3.

Nowak C., Prokuratura Europejska - idea się urzeczywistnia, „Prokuratura i Prawo” 2013, nr 11. Półtorak N., Przystapienie do Konwencji o Ochronie Praw Cztowieka i Podstawowych Wolności z perspektywy Unii Europejskiej, [w:] Obywatel w Radzie Europy i Unii Europejskiej. Nowe wyzwania po dwudziestu latach od przystapienia przez Polskę do Konwencji o Ochronie Praw Cztowieka i Podstawowych Wolności, Warszawa 2014.

Sicurella R., Setting up a European Criminal Policy for the Protection of EU Financial Interests. Guidelines for a Coherent Definition of the Material Scope of the European Public Prosecutor's Office, [w:] Toward a Prosecutor for the European Union, Vol. 1: A Comparative Analysis, red. K. Ligeti, Oxford-Portland 2013.

Stawicka P., Przystapienie UE do Konwencji o ochronie praw cztowieka i podstawowych wolności, 7 X 2014, [online] www.psz.pl/121.

Stronikowska G., Propozycja Komisji Europejskiej dotyczaca rozporządzenia Rady w sprawie utworzenia Prokuratury Europejskiej (część 1), „Prokuratura i Prawo” 2014, nr 6.

Wyrozumska A., Umocnienie ochrony praw podstawowych, [w:] Traktat z Lizbony. Gtówne reformy ustrojowe Unii Europejskiej, red. nauk. J. Barcz, Warszawa 2008.

Prof. Janusz Józef WĘC - profesor zwyczajny nauk humanistycznych w zakresie historii powszechnej najnowszej i stosunków międzynarodowych. Kierownik Katedry Studiów nad Procesami Integracyjnymi w Instytucie Nauk Politycznych i Stosunków Międzynarodowych Uniwersytetu Jagiellońskiego w Krakowie. Autor ponad 200 publikacji naukowych wydanych w kraju i za granicą, w tym 17 monografii i syntez, na temat ustroju Wspólnot Europejskich i Unii Europejskiej, integracji europejskiej i pozaeuropejskiej, stosunków polsko-niemieckich, najnowszej historii Niemiec, a także niemieckiego systemu politycznego. Ostatnio wydane monografie: Pierwsza polska prezydencja w Unii Europejskiej. Uwarunkowania - Procesy decyzyjne - Osiagnięcia i niepowodzenia (Kraków 2012); Spór o ksztatt ustrojowy Wspólnot Europejskich i Unii Europejskiej w latach 1950-2010. Między idea ponadnarodowości a wspótpraca międzyrzadowa. Analiza politologiczna (Kraków 2012); Traktat Lizboński. Polityczne aspekty reformy ustrojowej Unii Europejskiej w latach 2007-2009 (Kraków 2011); Sozialliberale Ostpolitik. Die FDP und der Warschauer Vertrag. Die Haltung der FDP gegenüber den Verhandlungen mit Polen über den Warschauer Vertrag vom 7. Dezember 1970 (Potsdam 2011). 